Best Practices

\title{
@ Telemedicine During COVID-19 and Beyond: A Practical Guide and Best Practices Multidisciplinary Approach for the Orthopedic and Neurologic Pain Physical Examination
}

Sayed Wahezi, MD1, Robert A. Duarte, MD², Sandeep Yerra, MBBS1, Mark A. Thomas, MD', Beendu Pujar, MD', Nalini Sehgal, MD³, Charles Argoff, MD¹, Laxmaiah Manchikanti, MD4, David Gonzalez, MD1', Ruchi Jain, MD1', Chong Kim, MD¹, Michael Hossack, MD1, Shayan Senthelal, MD1', Ankush Jain, MD1', Nathanael Leo, MD1', Naum Shaparin, MD1, Daniel Wong, MD'1, Ashley Wong, MD1, Kim Nguyen, MD'1, Jaspal Ricky Singh, MD, Giacinto Grieco, MD², Arpan Patel, MD², Merritt D. Kinon, MD', and Alan David Kaye, MD, PhD ${ }^{6}$

From: ${ }^{1}$ Montefiore Medical Center, Bronx, NY; ${ }^{2}$ Northwell Health, NY; 3 University of Wisconsin School of Medicine and Public Health, Madison, WI; ${ }^{4}$ Pain Management Centers of America, Paducah, KY; ${ }^{5}$ Weill

Cornell Medicine, New York, NY; ' $L S U$ School of Medicine,

Shreveport, LA and New Orleans, LA and Tulane School of

Medicine, New Orleans, LA

Address Correspondence: Sandeep Yerra, MD Montefiore Medical Center Department of Rehabilitation Medicine

150 E. 210th Street Bronx, NY 10467 E-mail:

drsandeepyerra@gmail.com

Disclaimer: There was no external funding in the preparation of this manuscript.

Conflict of interest: Dr. Kaye is a speaker for Merck. Dr. Wahezi is a consultant for Boston Dynamic.

Manuscript received: 05-20-2020 Revised manuscript received: 06-18-2020

Accepted for publication: 07-12-2020

Free full manuscript: www.pain physicianjournal.com
Background: The COVID pandemic has impacted almost every aspect of human interaction, causing global changes in financial, health care, and social environments for the foreseeable future. More than 1.3 million of the 4 million cases of COVID-19 confirmed globally as of May 2020 have been identified in the United States, testing the capacity and resilience of our hospitals and health care workers. The impacts of the ongoing pandemic, caused by a novel strain of severe acute respiratory syndrome coronavirus 2 (SARS-CoV-2), have far-reaching implications for the future of our health care system and how we deliver routine care to patients. The adoption of social distancing during this pandemic has demonstrated efficacy in controlling the spread of this virus and has been the only proven means of infection control thus far. Social distancing has prompted hospital closures and the reduction of all non-COVID clinical visits, causing widespread financial despair to many outpatient centers. However, the need to treat patients for non-COVID problems remains important despite this pandemic, as care must continue to be delivered to patients despite their ability or desire to report to outpatient centers for their general care. Our national health care system has realized this need and has incentivized providers to adopt distance-based care in the form of telemedicine and video medicine visits. Many institutions have since incorporated these into their practices without financial penalty because of Medicare's 1135 waiver, which currently reimburses telemedicine at the same rate as evaluation and management codes (E/M Codes). Although the financial burden has been alleviated by this policy, the practitioner remains accountable for providing proper assessment with this new modality of health care delivery. This is a challenge for most physicians, so our team of national experts has created a reference guide for musculoskeletal and neurologic examination selection to retrofit into the telemedicine experience.

Objectives: To describe and illustrate musculoskeletal and neurologic examination techniques that can be used effectively in telemedicine.

Study Design: Consensus-based multispecialty guidelines.

Setting: Tertiary care center.

Methods: Literature review of the neck, shoulder, elbow, wrist, hand, lumbar, hip, and knee physical examinations were performed. A multidisciplinary team comprised of physical medicine and rehabilitation, orthopedics, rheumatology, neurology, and anesthesia experts evaluated each examination and provided consensus opinion to select the examinations most appropriate for telemedicine evaluation. The team also provided consensus opinion on how to modify some examinations to incorporate into a nonhealth care office setting.

Results: Sixty-nine examinations were selected by the consensus team. Household objects were identified that modified standard and validated examinations, which could facilitate the examinations. The consensus review team did not believe that the modified tests altered the validity of the standardized tests. 
Limitations: Examinations selected are not validated for telemedicine. Qualitative and quantitative analyses were not performed.

Conclusions: The physical examination is an essential component for sound clinical judgment and patient care planning. The physical examinations described in this manuscript provide a comprehensive framework for the musculoskeletal and neurologic examination, which has been vetted by a committee of national experts for incorporation into the telemedicine evaluation.

Key words: COVID, pain, telemedicine, physical examination, spine, shoulder, elbow, hand, hip, knee

Pain Physician 2020: 23:S205-S237

A s of May 28, 2020, the coronavirus COVID-19 death toll exceeded 100,000, even though the country as a whole remains eighth among the global population based on deaths per 100,000 , causing unprecedented economic recession and health care crisis (1). The impacts of the ongoing pandemic, caused by a novel strain of severe acute respiratory syndrome coronavirus 2 (SARS-CoV-2), have far-reaching implications for the future of our health care system and how we deliver routine care to patients.

Nationally, the epidemiologic novelty of COVID-19 revealed vulnerabilities in existing supply chains, resulting in unprecedented social and economic disruptions and pressure on the health care system. In April, the U.S. Department of Health and Human Services released a report based on survey responses submitted by 323 hospitals, which detailed severe shortages of personal protective equipment (PPE), issues with adequate staffing levels, and a paucity of hospital capacity and ancillary supplies necessary to safely care for patients (2). Our health care system has addressed these challenges with innovative workarounds, including utilizing 3D-printed PPE, addressing capacity needs by reallocating physicians and nurses, and implementing electronic consultations (E-consults) for inpatient specialist services and televisits for the outpatient setting to adhere to social distancing guides for infection control, and to reserve PPE usage for health care workers in direct contact with COVID-infected patients.

COVID has changed how health care is practiced in the United States. It may permanently impact how we deliver care. Personal distancing during this time of COVID control has created an environment of social caution, and a need for clinical reform. The use of telemedicine has been on the rise in many regions and it is not evident when this trend will stop. Its use may be favored by patients who have difficulty traveling to physician offices, and some practitioners prefer telemedicine for noncomplicated follow-up visits. However, patients with a new pain complaint can be challenging, as there is minimal education directed toward proper examination of these patients. There is a paucity of published literature on the subject. Graduate medical education does not recognize telemedicine as a competency for the pain specialist, making an evidence-based platform for the telemedicine physical examination in the near future unlikely (3). However, the authors maintain that the telemedicine musculoskeletal and neurologic physical examination can be assessed accurately if 4 principles are followed: (1) ability of the practitioner to perform an appropriate regional anatomic inspection; (2) while recognizing normal versus pathological motion; (3) proper preparation and utilization of electronic devices by the patient; and (4) appropriate direction of the patient by the physician. Here we deliver practical guidance for the understanding and execution of the physical examination that is fundamental for clinical decision-making.

The development of an effective and efficient telemedicine arm of a practice is dependent on education of specific members of the administration and clinical team. Because this service is very new in clinical literature and is underused even by the most experienced practitioners, the onus for improvement rests on practitioners who have been using the service often to report the benefits and pitfalls. A major aim of this investigation is to facilitate this process by introducing our recommendations.

The patient telemedicine video visit should simulate the environment of an office visit. Thus the patient's room should be well lit, free of noise and distraction, have seating and the space to stand and to walk short distances. Common household items, which will serve as props for the examination, must also be easily accessible. These examination props are outlined in the tables later. A kitchen usually fulfills most of the criteria 
described earlier. Proper clothing is also required. For instance, shorts are to be worn for a below the waist complaint, and a T-shirt for above the waist examination. The physician's call center should inform the patient of these directions well before the visit. Proper preparation decreases the nonclinical instruction time during the visit. If the patient is using a phone for the video interaction, then the phone must be positioned self-standing on a sturdy surface so both of the patient's hands are available to perform tasks during the examination. The camera distance should be approximately 6 feet $(2 \mathrm{~m})$ away from the patient. For most patients, this is the appropriate distance for the practitioner to view a torso without having to relocate the device. The physician should be notified of the nature of the pain location prior to the visit so that the practitioner can be ready to guide the patient through the examination with their own set of props.

The telemedicine examination should be focused on the region of the pain and then extended beyond from that region depending on patients' symptoms of pain and their examination findings. The recommendations made in this review are meant to serve as guidelines only. Deciding which examination techniques to employ and when to use the technique goes beyond the scope of this manuscript. In many cases a diagnosis can be made with the directions provided here. However, it is at the discretion of the practitioner to perform an office visit if the recommendations here are insufficient to establish a diagnosis or uncover the need for an inoffice visit for clarification of medical planning.

\section{Methods}

Twenty nationally recognized leaders in their fields who have been using telemedicine since its rise in popularity developed and cross-evaluated physical examinations for applicability to the telemedicine platform. The examinations chosen were based on the ease with which the practitioner could instruct patients properly, and on their adaptability to perform the motions safely in a nonoffice environment without changing validity. An expert group comprised of physical medicine and rehabilitation specialists, orthopedists, rheumatologists, neurologists, and anesthesiologists was tasked with creating a musculoskeletal or neurologic physical examination appropriate for incorporation into the virtual workup. Each specialist designed an anatomically based examination that they were most familiar with. For example, the shoulder examination was created by a board-certified sports medicine shoulder specialist; however, all evaluators are skilled in every regional examination in this report. After creation of the region-based anatomic examination, all members of the group, as well as an outside committee comprised of the same specialties, reviewed, selected, and modified the examinations based on the same criteria.

\section{Results}

After multidisciplinary design, selection, and consensus, the tables in this article were created to guide musculoskeletal specialists in the physical examination. More than 100 examinations were reviewed. Sixty-nine examinations were selected by the group.

\section{Neck}

Neck pain is one of the leading causes of disability, with an annual prevalence between $15 \%$ and $50 \%$ (4-9). Almost half of the individuals will continue to experience pain or suffer from recurrence. History and physical examination can provide important clues as to whether the pain is neuropathic or mechanical and can also be used to identify "red flags" that may signify serious pathology. A summary of instructions for the neck examination is provided in Table 1.

\section{Shoulder}

A telemedicine examination of the shoulder should follow the principles of the general shoulder examination and begin with a thorough history, inspection, palpation, provocative tests, ROM, and strength testing (13). Shoulder pain encompasses a wide breadth of pathologies, including arthritis, rotator cuff pathology, instability, acromioclavicular joint pathology, biceps pathology, labral pathology, and infection, as well as conditions of the cervical spine masquerading as shoulder pain (14-18). A summary of instructions for the shoulder examination are summarized in Table 2.

\section{Hand/Wrist/Elbow}

Evaluation of the hand/wrist/elbow is an integral aspect of assessing upper extremity functioning and musculoskeletal disorders. After a detailed clinical history, the examination may be targeted to the areas of concern. Thorough inspection of the hand/wrist and elbow, ROM/strength testing, along with specialized examinations for certain ligamentous/tendon abnormalities and carpometacarpal (CMC) degenerative disease may be performed via telemedicine. A summary of instructions for the hand/wrist/elbow examination are summarized in Table 3. 
Pain Physician: August 2020 COVID-19 Special Issue 23:S205-S237

Table 1. Guide to the modified neck examination through telemedicine.

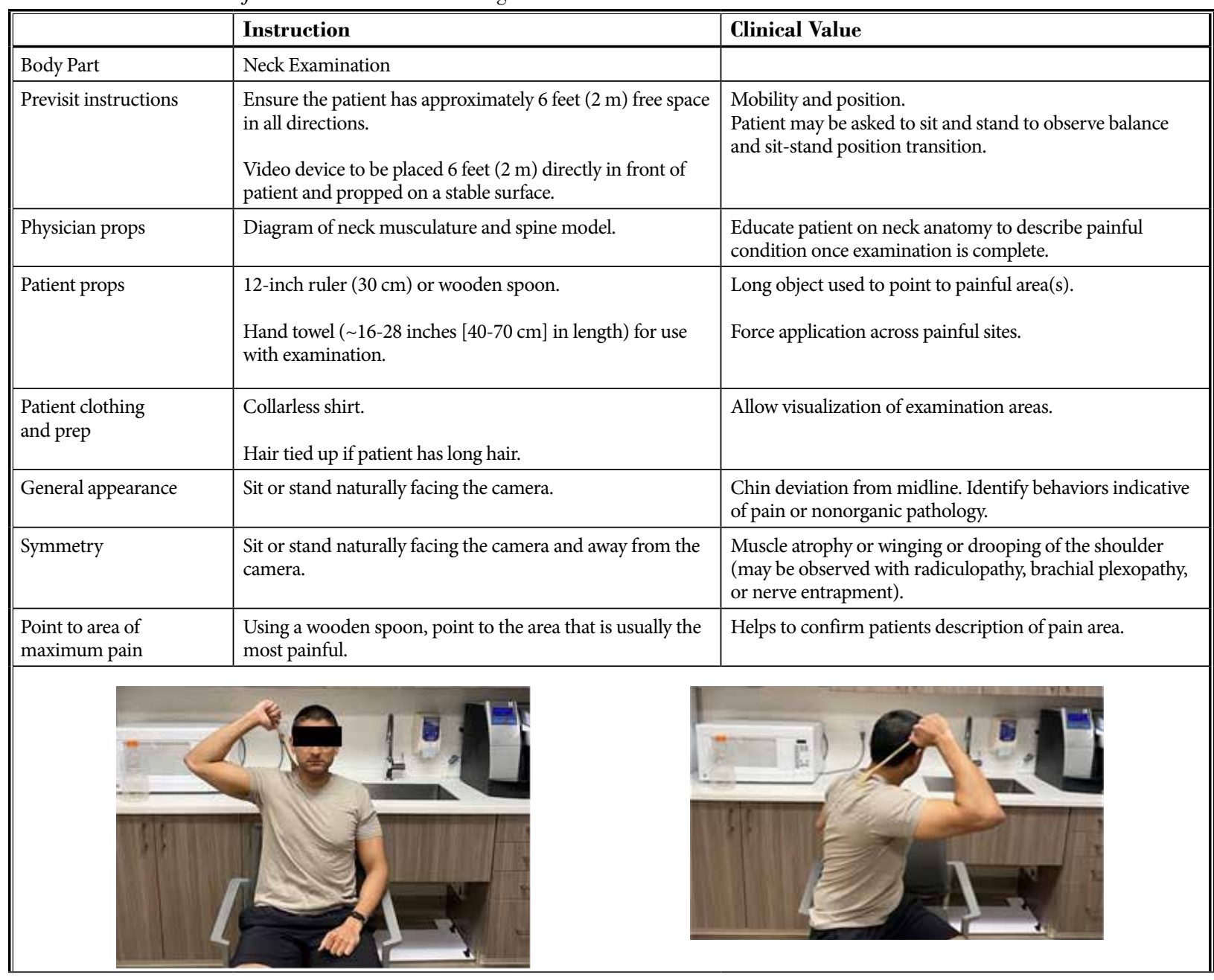

\begin{tabular}{|l|l|l|}
\hline & Instruction & Clinical Value \\
\hline Range of motion (ROM) & $\begin{array}{l}\text { Move chin to touch the chest. } \\
\text { Tilt head back. } \\
\text { Turn neck to move the chin to the shoulder. } \\
\text { Repeat to other side. } \\
\text { Tilt head so that ear goes to the shoulder on one side. } \\
\text { Repeat on other side. }\end{array}$ & $\begin{array}{l}\text { Abnormal lateral or forward flexion, or rotation, may } \\
\text { indicate torticollis. } \\
\text { Failure of chin to return to vertical/horizontal midline may } \\
\text { suggest dystonia. }\end{array}$ \\
\hline
\end{tabular}


Table 1 (cont.). Guide to the modified neck examination through telemedicine.

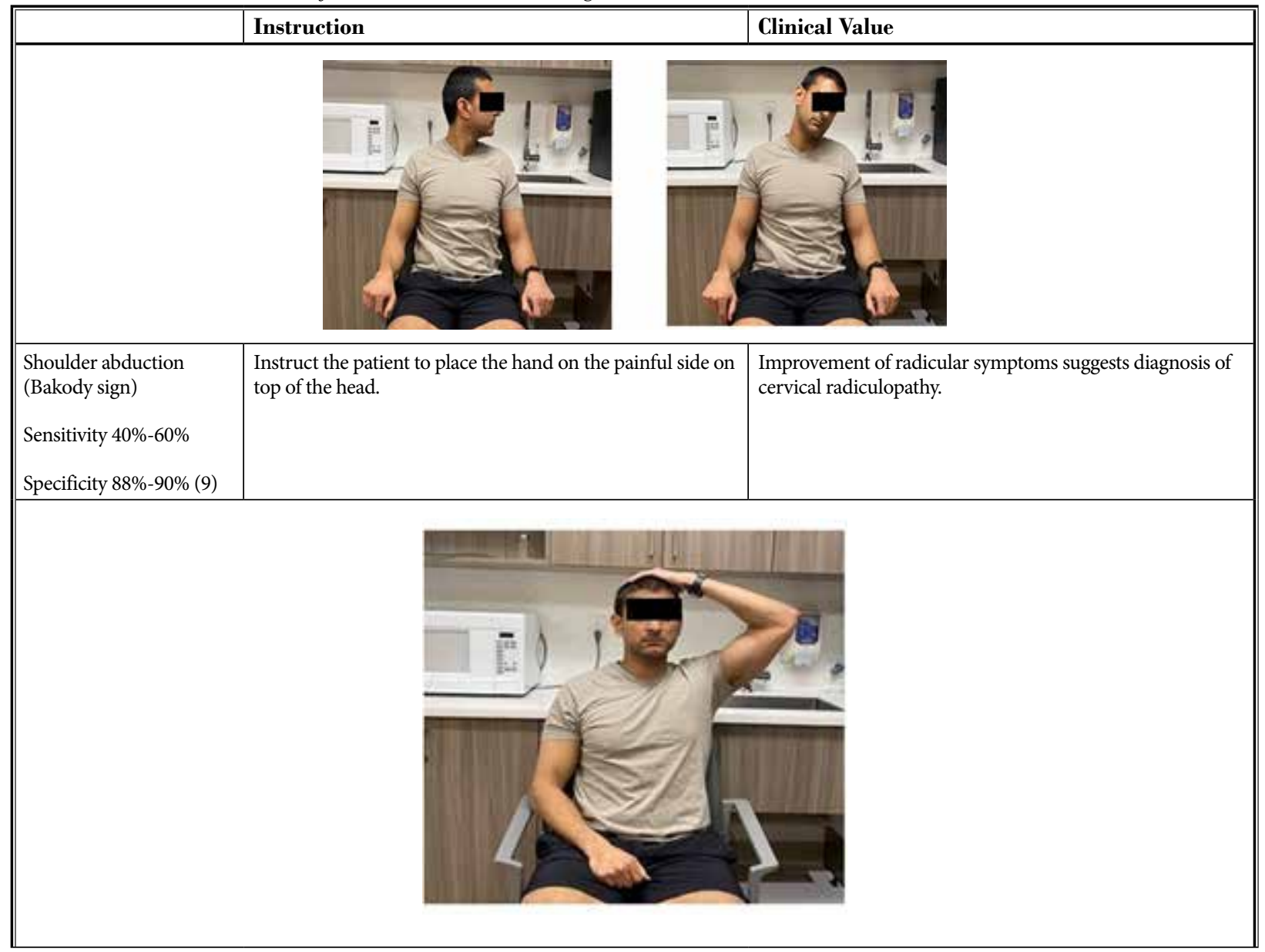

\begin{tabular}{||l|l|l||}
\hline & Instruction & Clinical Value \\
\hline $\begin{array}{l}\text { Valsalva } \\
\text { Sensitivity 22\% }\end{array}$ & $\begin{array}{l}\text { Instruct patient to "bear down" or try to breath out } \\
\text { forcefully with their mouth and nose closed. }\end{array}$ & Referred electric sensation suggests cervical radiculopathy. \\
Sensitivity 65\% & Instruct patient to rest their chin on their chest. & $\begin{array}{l}\text { Shock-like sensation in arms/legs suggests cervical } \\
\text { myelopathy or meningeal irritation. }\end{array}$ \\
Specificity 97\% (11) & $\begin{array}{l}\text { Note: neck pain without electrical sensation suggests } \\
\text { trapezius and/or splenius as source of pain. }\end{array}$ \\
\hline 'Hermitte sign &
\end{tabular}


Table 1 (cont.). Guide to the modified neck examination through telemedicine.

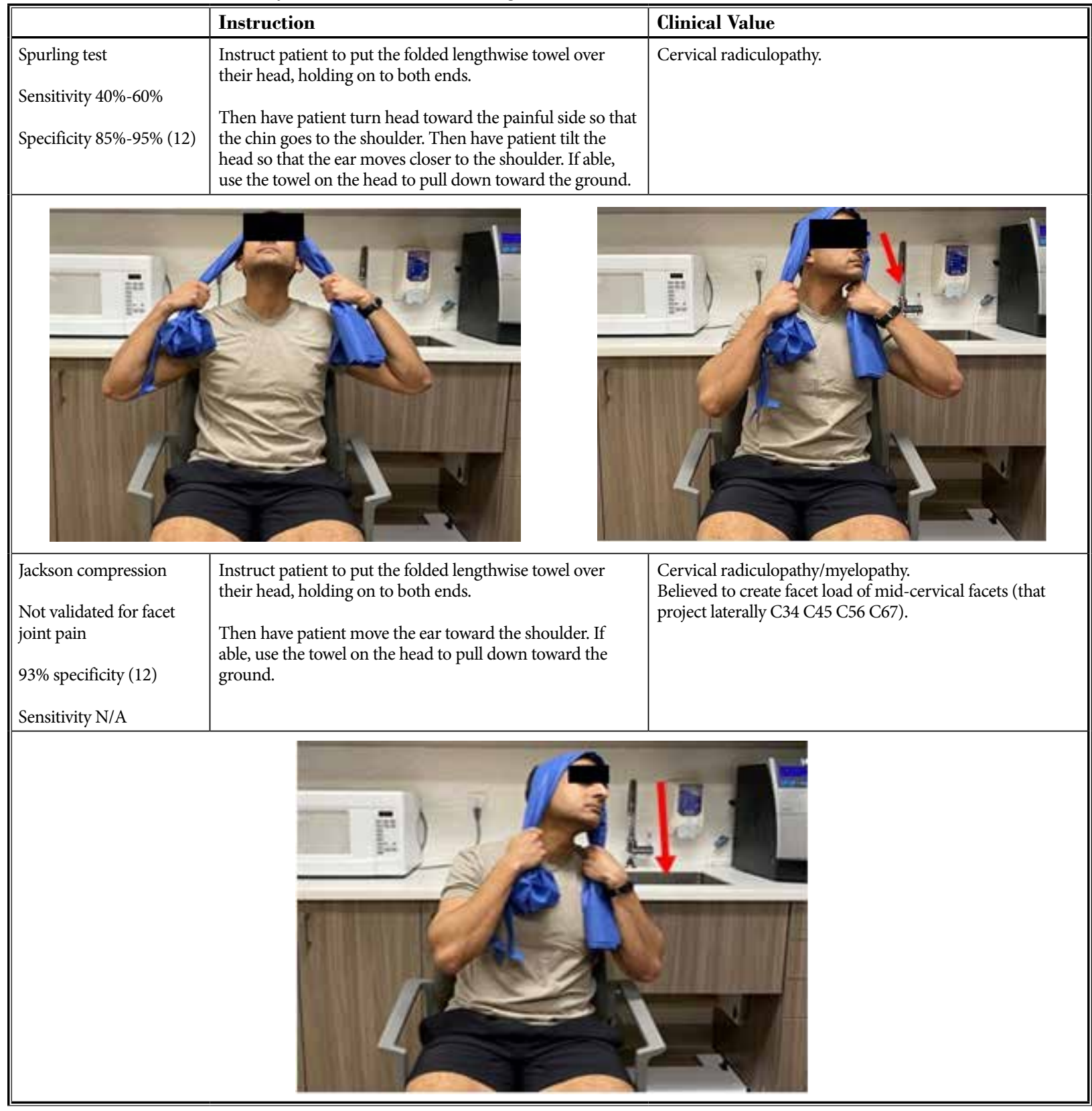

\section{Lumbar Spine}

Lower back pain causes significant disability and social burden worldwide. Pain is a self-reported symptom that is subject to multiple biases, both from the patient and evaluating physician. Particularly with lower back pain, which can have a significant psychosocial component, a good objective physical examination is key to an accurate diagnostic workup. An accurate diagnosis is crucial when deciding on the appropriate treatment and utilization of resources for favorable outcomes of lower back pain. Many different diagnoses present with similar clinical histories. Because of the anatomic location and multifactorial nature of lower back pain, identifying the source of pain has been especially challenging for clinicians. Nearly every element of the lower back (muscle, bone, nerve, disc, etc.) has been implicated as a cause of lower back pain. With our transition to telemedicine, it is crucial that we optimize our 
Telemedicine During COVID-19 and Beyond

Table 2. Guide to the modified shoulder examination through telemedicine guide.

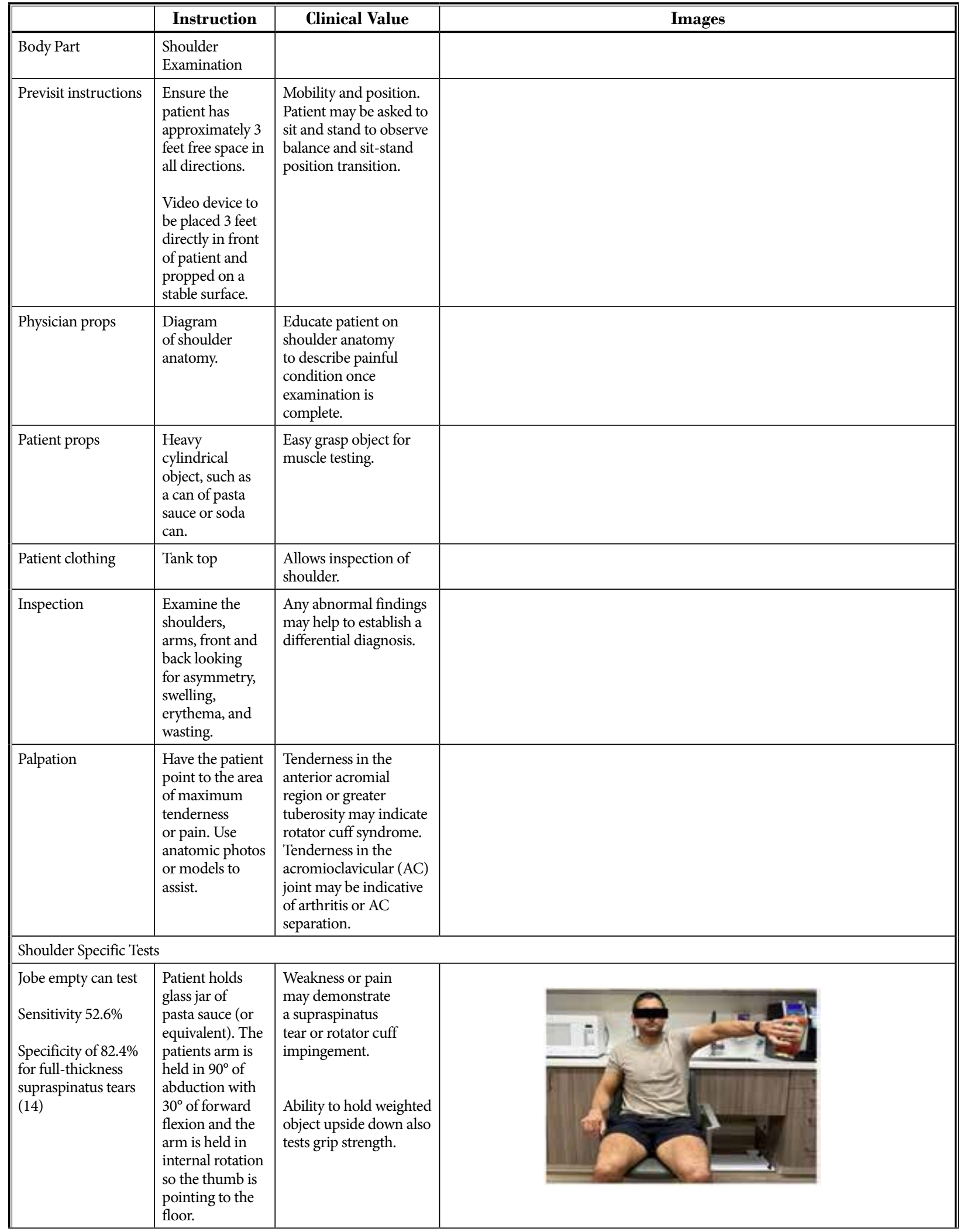


Table 2 con't. Guide to the modified shoulder examination through telemedicine guide.

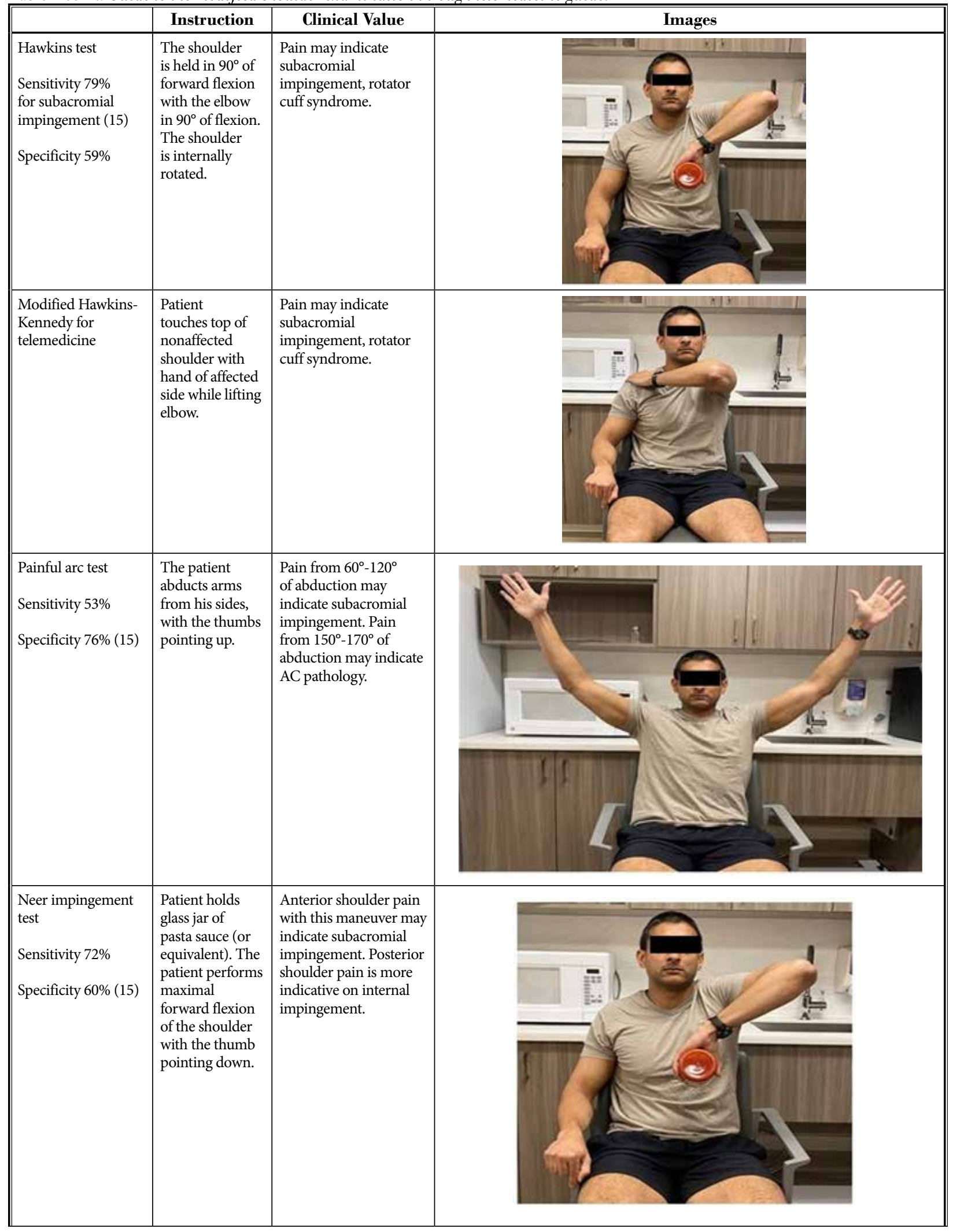


Table 2 con't. Guide to the modified shoulder examination through telemedicine guide.

\begin{tabular}{|c|c|c|c|}
\hline & Instruction & Clinical Value & Images \\
\hline $\begin{array}{l}\begin{array}{l}\text { Anterior } \\
\text { apprehension test }\end{array} \\
\text { Sensitivity } 72 \%-98 \% \\
\text { Specificity } 72 \%-96 \% \\
\text { (13) }\end{array}$ & $\begin{array}{l}\text { Typically used } \\
\text { for younger } \\
\text { patients (under } \\
30 \text { years of age). } \\
\text { Have the patient } \\
\text { position their } \\
\text { shoulder in } 90^{\circ} \\
\text { of abduction } \\
\text { and external } \\
\text { rotation. }\end{array}$ & $\begin{array}{l}\text { Apprehension or pain } \\
\text { in this position may } \\
\text { indicate moderate } \\
\text { anterior shoulder } \\
\text { instability or a possible } \\
\text { labral tear. }\end{array}$ & \\
\hline $\begin{array}{l}\text { Modified anterior } \\
\text { apprehension test } \\
\text { Sensitivity } \\
78 \% \\
\text { Specificity } \\
75 \%(19)\end{array}$ & $\begin{array}{l}\text { Can increase } \\
\text { the forces on the } \\
\text { anterior capsule } \\
\text { if patient places } \\
\text { elbow on a sold } \\
\text { vertical surface } \\
\text { and leans } \\
\text { forward } 10^{\circ}-20^{\circ} \text {. }\end{array}$ & $\begin{array}{l}\text { Apprehension or pain } \\
\text { in this position may } \\
\text { indicate small anterior } \\
\text { shoulder instability or a } \\
\text { possible labral tear. }\end{array}$ & \\
\hline $\begin{array}{l}\text { Cross-body } \\
\text { adduction } \\
\text { Sensitivity } 77 \% \\
\text { Specificity } 79 \% \text { for } \\
\text { AC joint pathology } \\
(20)\end{array}$ & $\begin{array}{l}\text { With the } \\
\text { shoulder in } 90^{\circ} \\
\text { of elevation } \\
\text { and the elbow } \\
\text { straight, the } \\
\text { patient should } \\
\text { reach across } \\
\text { their body as far } \\
\text { as possible using } \\
\text { the contralateral } \\
\text { arm to adduct } \\
\text { the shoulder. }\end{array}$ & $\begin{array}{l}\text { Pain in the AC joint } \\
\text { region with this } \\
\text { provocative test may } \\
\text { indicate AC pathology. }\end{array}$ & \\
\hline $\begin{array}{l}\text { Speeds test } \\
\text { Sensitivity } 32 \% \\
\text { Specificity } 61 \%(16)\end{array}$ & $\begin{array}{l}\text { With the hand } \\
\text { supinated } \\
\text { and arm } \\
\text { outstretched, } \\
\text { raise the arm } \\
\text { from the waist } \\
\text { while holding } \\
\text { a glass, can, or } \\
\text { half-filled 2 L } \\
\text { bottle of soda. }\end{array}$ & $\begin{array}{l}\text { Pain with this motion } \\
\text { may indicate biceps } \\
\text { tendon pathology } \\
\text { or superior labrum } \\
\text { pathology. }\end{array}$ & \\
\hline
\end{tabular}


Table 2 con't. Guide to the modified shoulder examination through telemedicine guide.

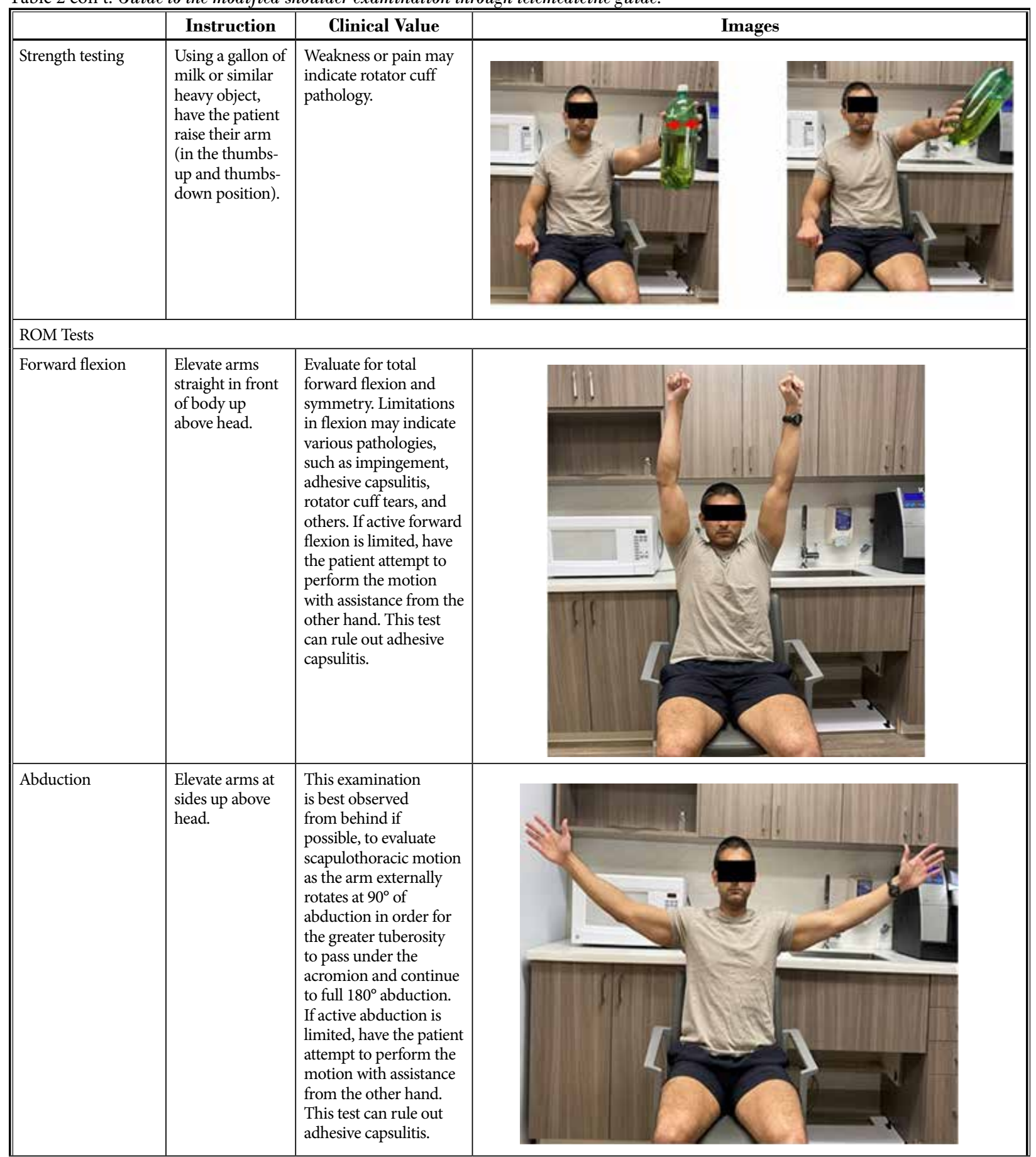

visual and patient-assisted examination skills (21-29). A summary of instructions for the back examination are summarized in Table 4.
Hip

The hip is a ball-and socket, diarthrodial, synovial joint. Pain originating from the joint is a fairly common complaint of patients presenting to pain clinics. Hip 
Table 2 con't. Guide to the modified shoulder examination through telemedicine guide.

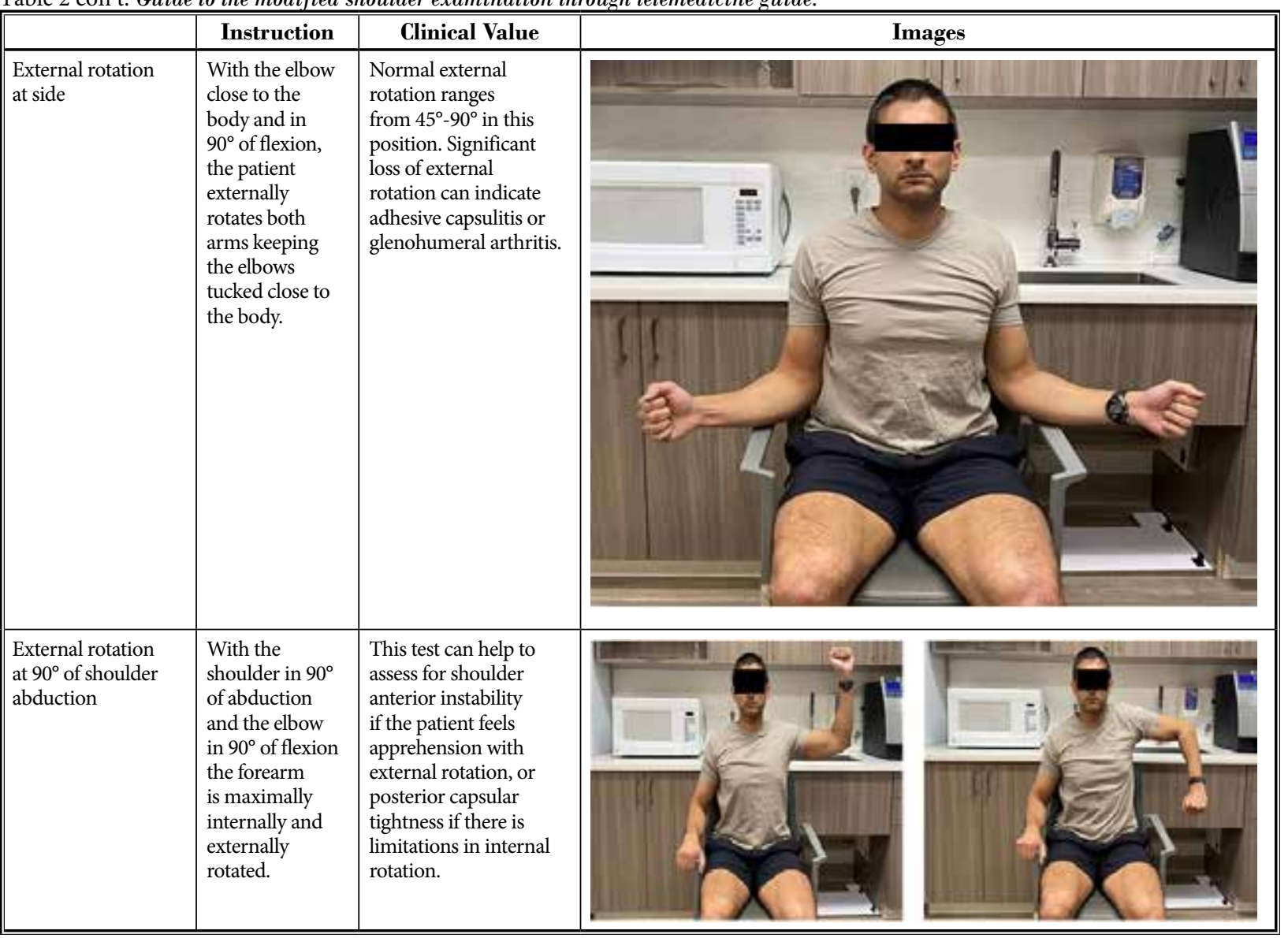

pain, of any pathology, affects approximately $14 \%$ of the general population over 60 years of age, and can be caused by a myriad of conditions, including myofascial origin, osteoarthritis, labral tear, femoroacetabular impingement, fracture, sacroiliac joint dysfunction, and greater trochanteric pain syndrome (33).

An adequate evaluation of the hip joint involves a thorough history and physical examination, with focus on inspection, ROM, palpation, and provocative tests, and can be further assisted with imaging, if available. A summary of instructions for the hip examination are summarized in Table 5.

\section{Knee}

Knee pain is common. The telemedicine knee examination should include a through history, inspection, palpation, ROM, and proactive test. There is a spectrum of pathologies causing knee pain, including arthritis, meniscus injury, cruciate and collateral ligament injury, patella instability, osteochondral/fracture injury, and extensor mechanism rupture. The telemedicine knee examination can assist the physician to diagnose urgent injuries, which necessitate further attention, workup, and possibly surgery, from knee pathologies that can undergo conservative management (35-39). A summary of instructions for the knee examination are summarized in Table 6.

\section{Neurologic Examination}

The neurologic examination includes the following components: mental status assessment, cranial nerve evaluation, motor examination (including coordination and gait), sensory evaluation, evaluation of muscle stretches, as well as other reflexes and a neurovascular assessment. The American Academy of Neurology has recently released a guide to the neurologic examination for telemedicine on its website (41). The guide notes that certain portions of the examination, including the ophthalmologic examination, the vestibular examination, and the evaluation of slight weakness or sensory deficits, may be difficult to perform via telemedicine (41). Upper and lower extremity strength 
Table 3. Guide to the modified hand/wrist/elbow examination through telemedicine guide.

\begin{tabular}{|c|c|c|c|}
\hline & $\begin{array}{c}\text { Visualization/Patient } \\
\text { Instructions } \\
\end{array}$ & Clinical Value & Images \\
\hline Body Part & Hand/Wrist/Elbow & & \\
\hline $\begin{array}{l}\text { Previsit } \\
\text { instructions }\end{array}$ & $\begin{array}{l}\text { Ensure the patient has } \\
\text { approximately } 3 \text { feet free } \\
\text { space in all directions. } \\
\text { Video device to be placed 2-3 } \\
\text { feet directly in front of patient } \\
\text { and propped on a stable } \\
\text { surface. }\end{array}$ & $\begin{array}{l}\text { Mobility and position. } \\
\text { Patient may be asked to } \\
\text { sit and stand to observe } \\
\text { balance and sit-stand } \\
\text { position transition. }\end{array}$ & \\
\hline $\begin{array}{l}\text { Physician } \\
\text { props }\end{array}$ & Diagram of hand/wrist/elbow. & $\begin{array}{l}\text { Educate patient on } \\
\text { hand/wrist/elbow } \\
\text { anatomy to describe } \\
\text { painful condition once } \\
\text { examination is complete. }\end{array}$ & \\
\hline Patient props & $\begin{array}{l}\text { Mug with large handle, pen/ } \\
\text { pencil, sheet of paper, jar } \\
\text { with lid. }\end{array}$ & $\begin{array}{l}\text { Used for fine and gross } \\
\text { muscle motor evaluation. }\end{array}$ & \\
\hline $\begin{array}{l}\text { Patient } \\
\text { clothing }\end{array}$ & Short sleeves shirt. & $\begin{array}{l}\text { Allows inspection to } \\
\text { visualize hand, wrist, } \\
\text { forearm, and elbow. }\end{array}$ & \\
\hline Inspection & $\begin{array}{l}\text { Dorsal aspect: inspect wrist, } \\
\text { elbow, metacarpophalangeal } \\
\text { (MCP), proximal } \\
\text { interphalangeal (PIP), } \\
\text { and distal interphalangeal } \\
\text { (DIP) joints for swelling } \\
\text { or erythema. Look for } \\
\text { bony deformities including } \\
\text { Heberden and Bouchard } \\
\text { nodes. } \\
\text { Volar aspect: inspect the } \\
\text { thenar muscle at the radial } \\
\text { aspect of the palm at the } \\
\text { base of the thumb. Inspect } \\
\text { the hypothenar muscle at the } \\
\text { medial aspect above the wrist. }\end{array}$ & $\begin{array}{l}\text { Swelling and/or erythema } \\
\text { at MCPs/PIPs/DIPs } \\
\text { may represent synovitis. } \\
\text { Swelling of an entire digit } \\
\text { may represent dactylitis. } \\
\text { Squared appearance at } \\
\text { the base of the thumb } \\
\text { along with pain may } \\
\text { represent CMC arthritis. } \\
\text { Swelling at the olecranon } \\
\text { may represent olecranon } \\
\text { bursitis. Thenar atrophy } \\
\text { may represent carpal } \\
\text { tunnel syndrome/median } \\
\text { neuropathy. Hypothenar } \\
\text { muscle atrophy } \\
\text { may represent ulnar } \\
\text { neuropathy. }\end{array}$ & 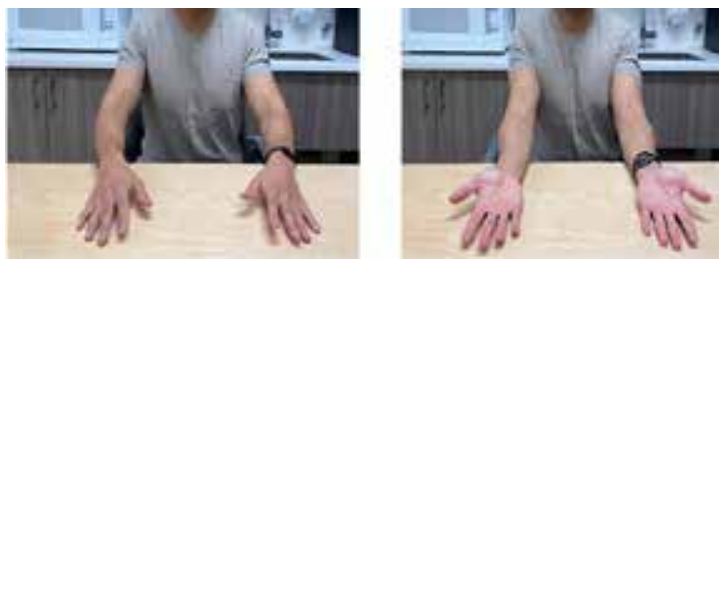 \\
\hline
\end{tabular}

can be assessed as noted earlier. Further motor examination testing can include watching how easily the person pulls him/herself up in bed, how easily he/she can stand up with arms crossed from seated or squatting, observing heel and toe walking, and assessing how well he/she stands on one leg. Additional testing can be considered if there is someone present with the patient being examined. Sensory testing is difficult to complete without another person present but can be attempted. In the tables, the key components of the examination, as well as tips regarding how to perform these components, are. During a telemedicine pain management assessment, it is anticipated that a relatively focused approach to the neurologic examination will be completed. For example, although all patients might be evaluated for their mental status examination during the telemedicine visit, the pain specialist may be focusing the neurologic assessment on the specific area of complaint. For the patient with low back pain and radicular complaints the examination will likely be focused on the lower extremity; for a person with more widespread complaints it may involve a broader assessment (42-44). A summary of instructions for the neurologic examination are summarized in Appendix 1. 
Telemedicine During COVID-19 and Beyond

Table 3 con't. Guide to the modified hand/wrist/elbow examination through telemedicine guide.

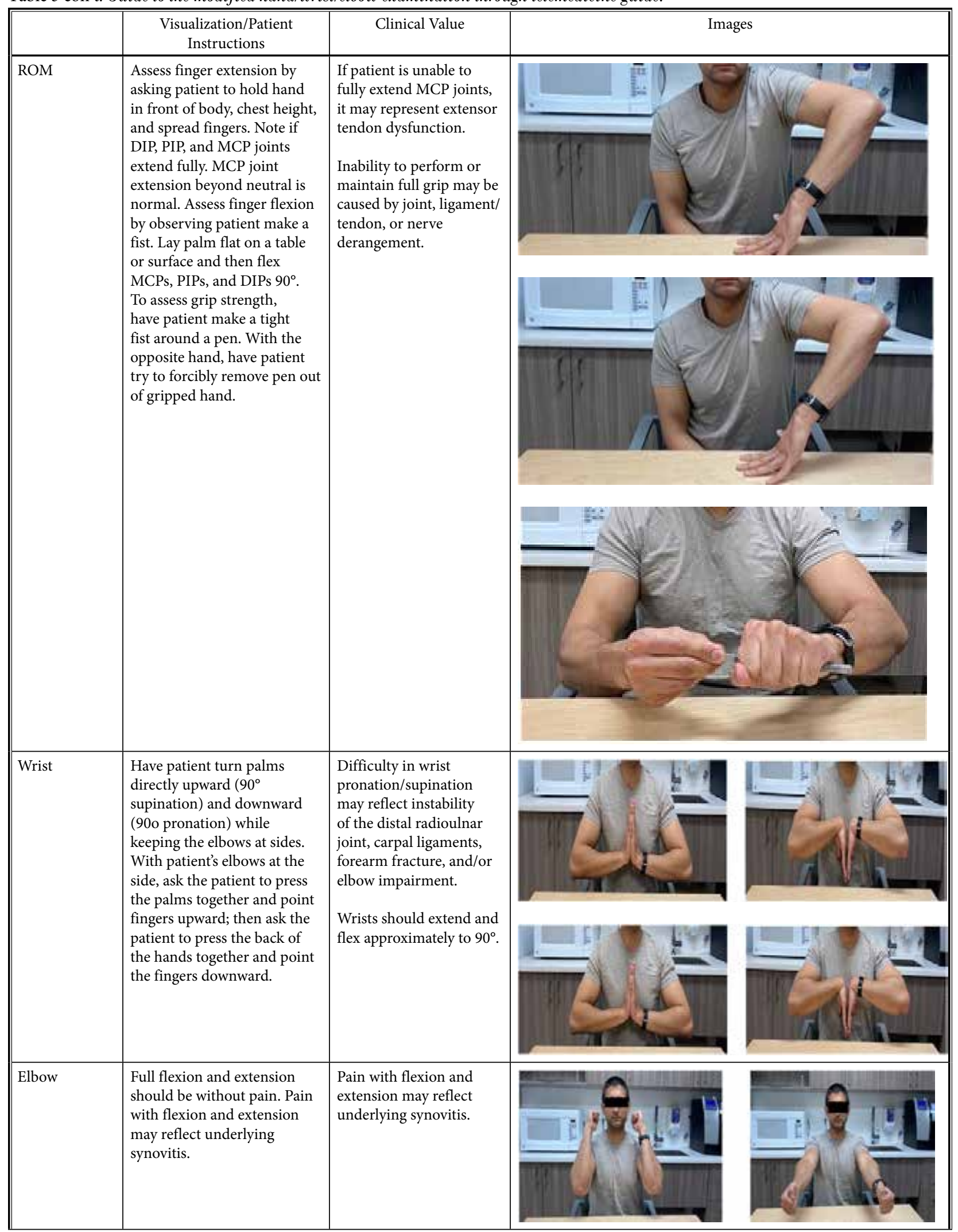


Table 3 con't. Guide to the modified hand/wrist/elbow examination through telemedicine guide.

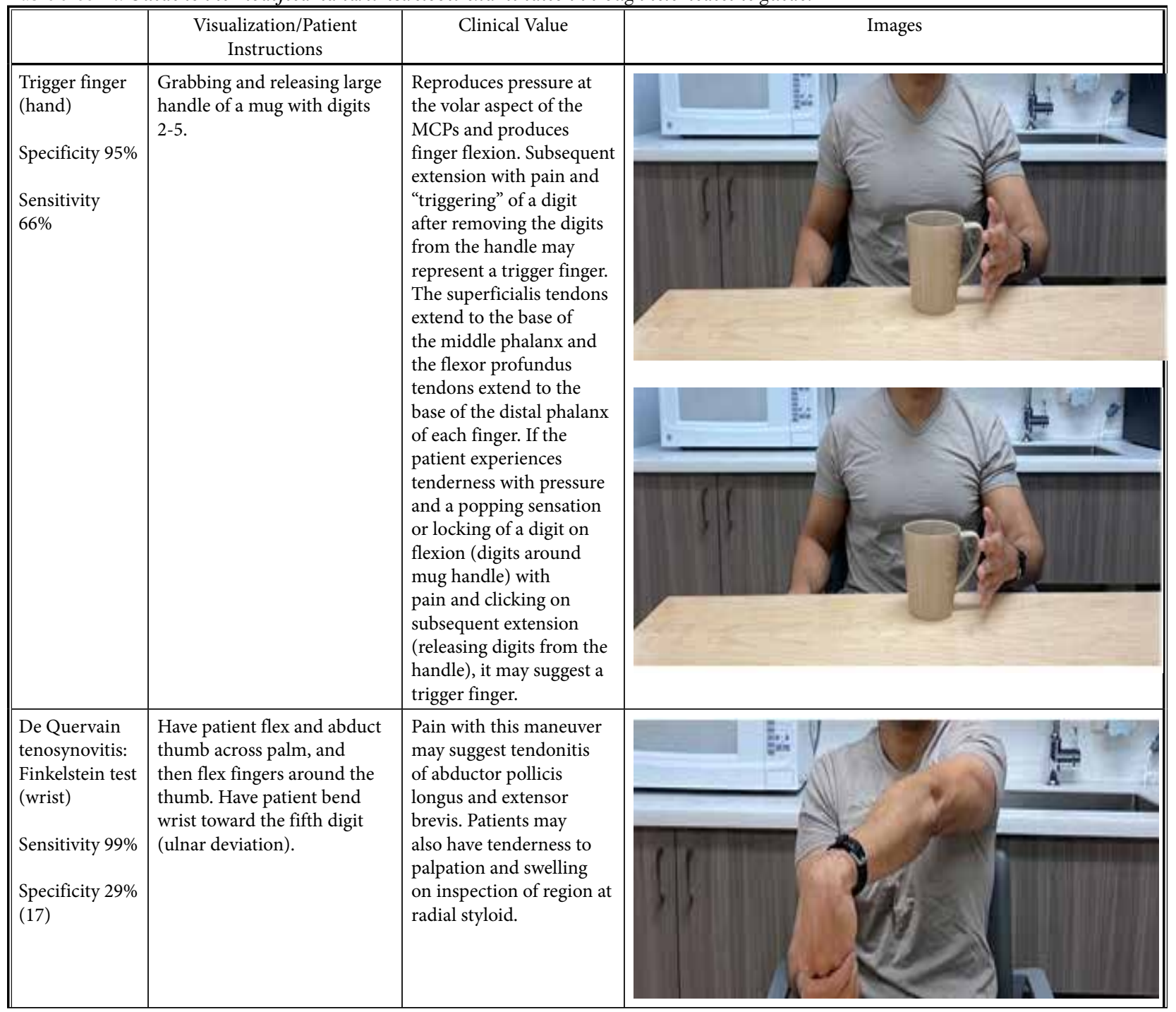


Telemedicine During COVID-19 and Beyond

Table 3 con't. Guide to the modified hand/wrist/elbow examination through telemedicine guide.

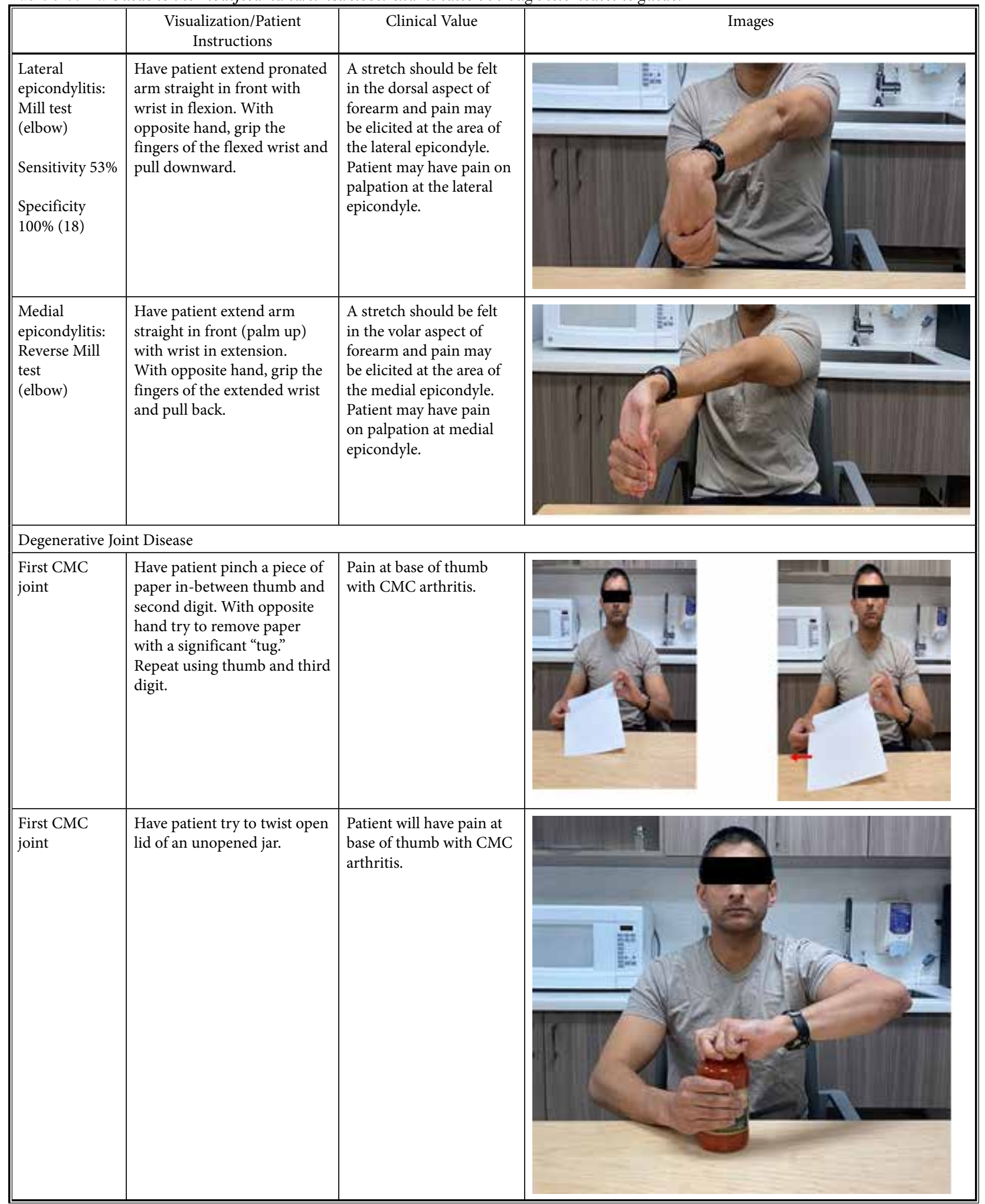


Table 4. Guide to the modified lumbar spine examination through telemedicine guide.

\begin{tabular}{|c|c|c|c|}
\hline & Instruction & Clinical Value & Images \\
\hline Body Part & Back Examination & & \\
\hline Previsit instructions & $\begin{array}{l}\text { Ensure the patient has } \\
\text { approximately } 6 \text { feet free } \\
\text { space in all directions. } \\
\text { Video device to be placed } \\
6 \text { feet directly in front of } \\
\text { patient and propped on a } \\
\text { stable surface. } \\
\text { Position the device to be able } \\
\text { to visualize from head to toe. }\end{array}$ & $\begin{array}{l}\text { Mobility and position. } \\
\text { Patient may be asked to } \\
\text { sit and stand to observe } \\
\text { balance and sit-stand } \\
\text { position transition. }\end{array}$ & \\
\hline Physician props & Spine model. & $\begin{array}{l}\text { Educate patient on lumbar } \\
\text { anatomy to describe } \\
\text { painful condition once } \\
\text { examination is complete. }\end{array}$ & \\
\hline Patient props & $\begin{array}{l}\text { Chair, bed, or couch. } \\
\text { Q-tip for light touch testing. } \\
\text { Wooden spoon. }\end{array}$ & $\begin{array}{l}\text { Assess position changes. } \\
\text { Point to painful area(s). }\end{array}$ & \\
\hline Patient clothing & Shorts and t-shirt. & $\begin{array}{l}\text { Allow easy visualization of } \\
\text { examination areas. }\end{array}$ & \\
\hline Activity & Instructions & Clinical Value & \\
\hline General appearance & $\begin{array}{l}\text { Patient to stand naturally in } \\
\text { front of camera. }\end{array}$ & $\begin{array}{l}\text { Asymmetry during } \\
\text { standing suggests limb or } \\
\text { lumbar pathology. } \\
\text { Patients with SIJ pain may } \\
\text { offload painful side. }\end{array}$ & \\
\hline Gait & $\begin{array}{l}\text { Instruct patient to walk } \\
\text { toward or away from the } \\
\text { camera and turn around and } \\
\text { walk back. }\end{array}$ & $\begin{array}{l}\text { Gait assessment. } \\
\text { Antalgia suggests painful } \\
\text { hip, knee, ankle, foot. } \\
\text { Increased hip rise may } \\
\text { mean that patient is unable } \\
\text { to clear the floor normally } \\
\text { with foot. } \\
\text { Consider weak dorsiflexors } \\
\text { as explanation. } \\
\text { Cross-reference with heel } \\
\text { walk } \\
\text { suggests (L4) nerve root } \\
\text { pathology (24). }\end{array}$ & \\
\hline
\end{tabular}


Telemedicine During COVID-19 and Beyond

Table 4 con't. Guide to the modified lumbar spine examination through telemedicine guide.

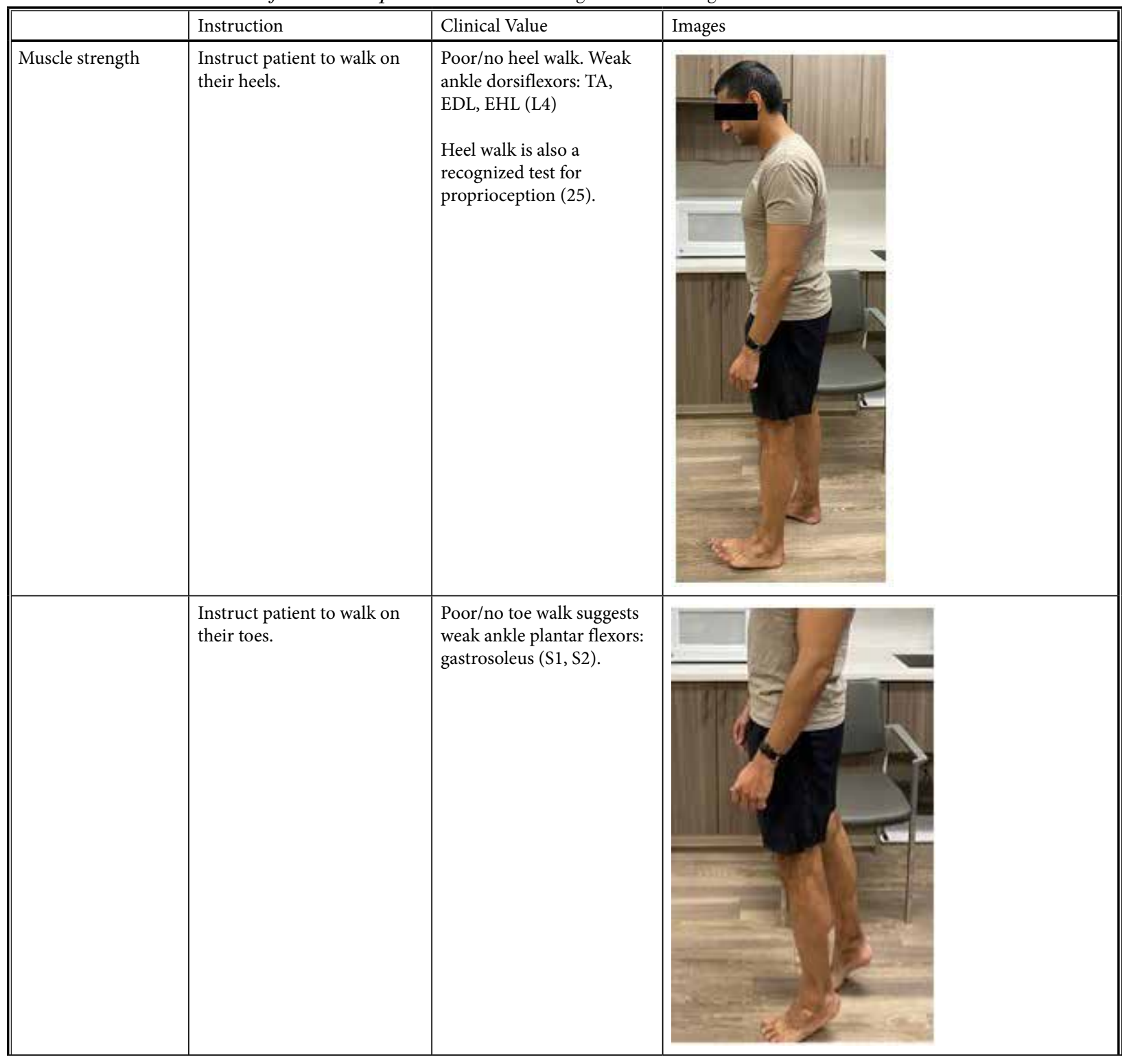

\section{Discussion}

Telemedicine requires the clinician to greatly focus on observation skills. Ironically, medicine has lost much of this emphasis in contrast to how it was taught and practiced centuries ago. According to Sir William Osler's own words, "The student starts . . . as an observer of ....structure and orderly functions of which he is perfectly familiar. Teach him how to observe.... The whole art of medicine is in observation" (41).

The explosive growth of telemedicine will require providers to use their clinical skills in a novel venue.
A conscientious history and physical examination are essential for patient diagnosis and management. The most meaningful aspects of this evaluative process can be performed through an audio/video format.

The history of the chief complaint, along with the past medical and functional history, provides the most necessary information but the physical examination remains an important screening tool to improve diagnostic accuracy, even when limited to those static, dynamic, and provoked signs of a patient's pathology that can be observed through a camera (45). Estimates 
Table 4 con't. Guide to the modified lumbar spine examination through telemedicine guide.

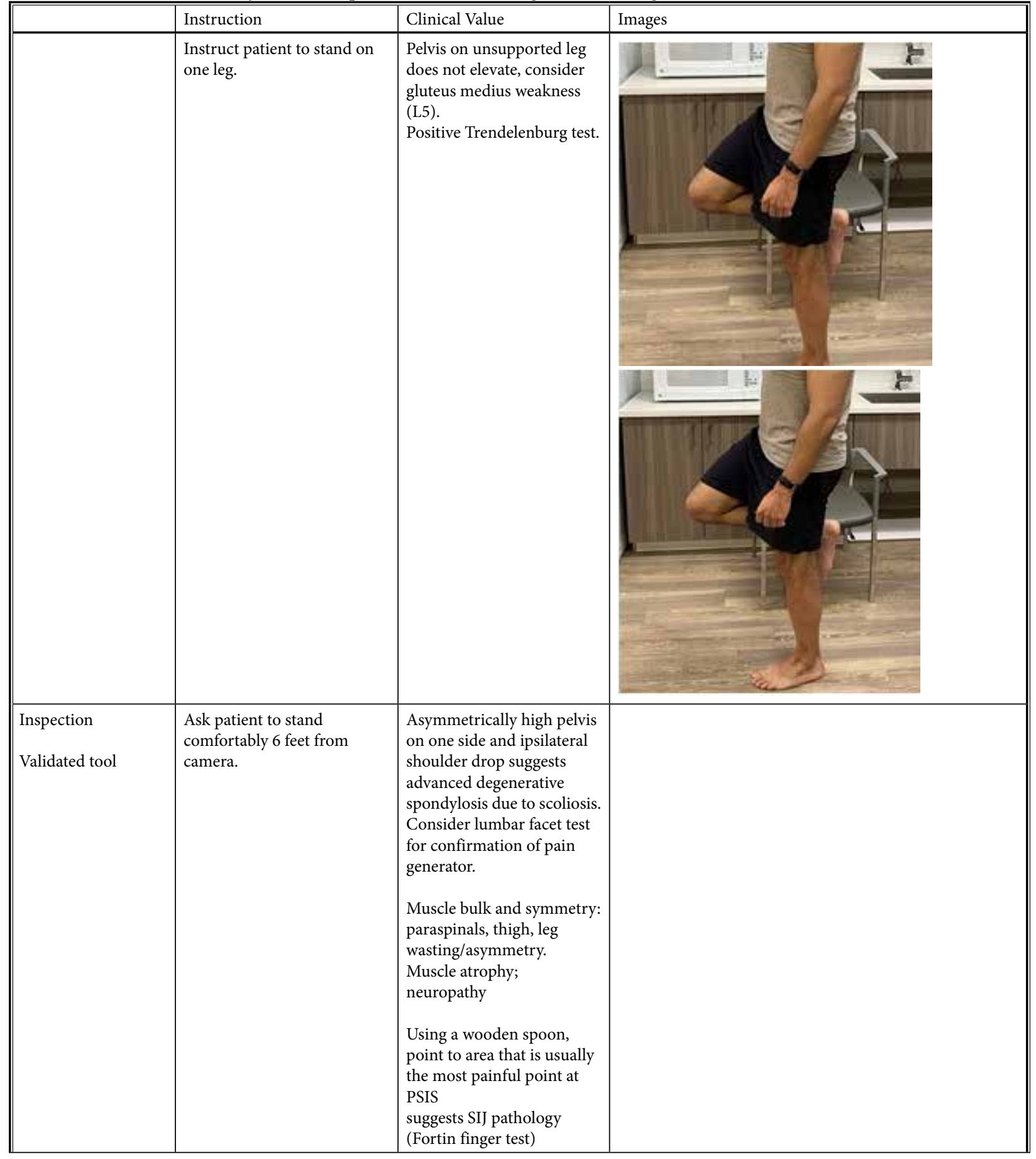


Telemedicine During COVID-19 and Beyond

Table 4 con't. Guide to the modified lumbar spine examination through telemedicine guide.

\begin{tabular}{|c|c|c|c|}
\hline & Instruction & Clinical Value & Images \\
\hline Posture & $\begin{array}{l}\text { Advise that patient stand } \\
\text { sideways in relation to the } \\
\text { video camera. }\end{array}$ & $\begin{array}{l}\text { Pronounced kyphosis } \\
\text { suggests old compression } \\
\text { fractures. } \\
\text { Spondylolisthesis. } \\
\text { Pronounced lumbar } \\
\text { lordosis suggests muscle } \\
\text { imbalances: weak } \\
\text { abdominal muscles, tight or } \\
\text { weak iliopsoas, hamstrings. } \\
\text { Hip flexion with forward } \\
\text { inclined trunk, flat back } \\
\text { sway back posture. }\end{array}$ & \\
\hline ROM & $\begin{array}{l}\text { Instruct the patient to turn } \\
\text { and touch their toes. }\end{array}$ & $\begin{array}{l}\text { Pain radiates into lower } \\
\text { limb/s w/flexion suggests } \\
\text { HNP, discogenic pain, } \\
\text { paraspinous spasm. } \\
\text { Pain without radiation } \\
\text { may suggest inflammatory } \\
\text { arthritis, Spondylosis. }\end{array}$ & \\
\hline ROM & $\begin{array}{l}\text { Instruct the patient to extend } \\
\text { their spine. }\end{array}$ & $\begin{array}{l}\text { Extension and referred } \\
\text { pain into lower limb/s w/ } \\
\text { extension suggests } \\
\text { central canal stenosis, } \\
\mathrm{HNP} / \text { nerve root irritation. } \\
\text { Pain without radiation } \\
\text { suggests facet pathology. }\end{array}$ & \\
\hline
\end{tabular}


Pain Physician: August 2020 COVID-19 Special Issue 23:S205-S237

Table 4 con't. Guide to the modified lumbar spine examination through telemedicine guide.

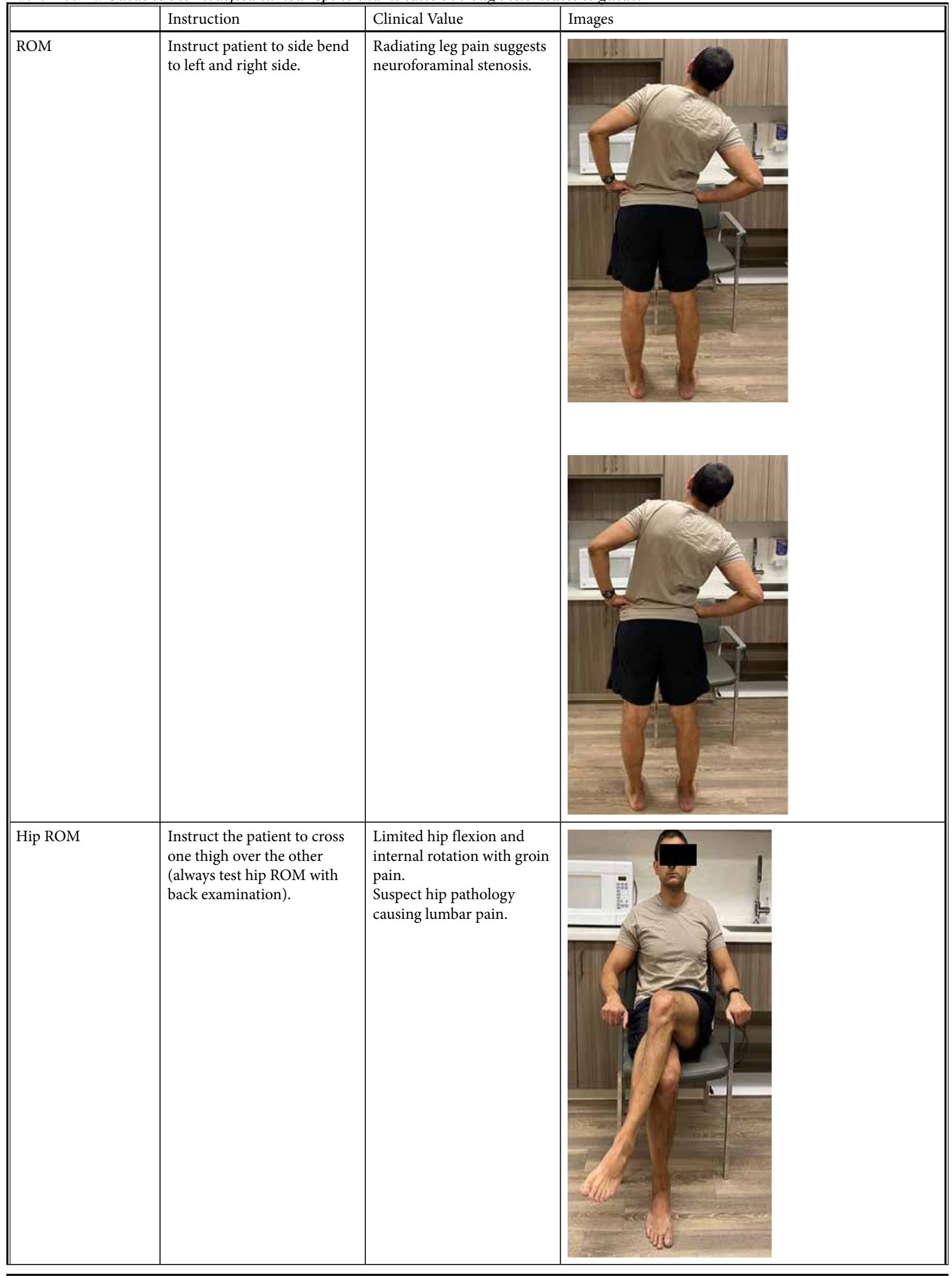


Telemedicine During COVID-19 and Beyond

Table 4 con't. Guide to the modified lumbar spine examination through telemedicine guide.

\begin{tabular}{|c|c|c|c|}
\hline & Instruction & Clinical Value & Images \\
\hline Palpation & $\begin{array}{l}\text { Instruct patient to press } \\
\text { hand over lumbar area } \\
\text { corresponding to spine, } \\
\text { quadratus lumborum, and } \\
\text { periiliac crest areas. }\end{array}$ & $\begin{array}{l}\text { Tenderness at lumbar } \\
\text { spinous process, sacrum, } \\
\text { facet/SIJ/paraspinal or } \\
\text { gluteal, piriformis muscles, } \\
\text { greater trochanters. } \\
\\
\text { Reproducible lumbar pain } \\
\text { with palpation may suggest } \\
\text { episacral fat pad as cause of } \\
\text { symptoms. }\end{array}$ & \\
\hline \multicolumn{4}{|l|}{ Sitting Maneuvers } \\
\hline $\begin{array}{l}\text { Slump test } \\
\text { Sensitivity } 84 \% \\
\text { Specificity } 83 \%(26)\end{array}$ & $\begin{array}{l}\text { Advise patient to place hands } \\
\text { behind back, then perform } \\
\text { chin to chest tuck and lean } \\
\text { forward, straighten out right } \\
\text { leg. Repeat with left side. }\end{array}$ & $\begin{array}{l}\text { Positive slump test: } \\
\text { reproducible and radiating } \\
\text { low back and lower limb } \\
\text { pain suggests HNP/nerve } \\
\text { root irritation. }\end{array}$ & \\
\hline
\end{tabular}

about the need for an in-person physical examination to reach a definitive diagnosis range between $10 \%$ and $15 \%$. Laboratory investigations, as easily guided from a telemedicine platform as from an office visit, contribute to a diagnosis at about the same rate and in many instances only confirm or exclude a diagnosis. The physical examination can also exclude diagnostic possibilities and increase diagnostic confidence (46). Seventy percent of clinicians worldwide feel that the physical examination is almost always valuable. The same study, however, reveals that approximately $85 \%$ of clinicians feel that physical examination of the joints, and in particular of the knee, is only valuable $30 \%$ to $40 \%$ of the time (47). The largest part of the physical examination is observation, with notable exceptions for diagnoses requiring auscultation (heart, lungs, abdomen) and expert palpation (abdomen, genitourinary system).

Observation is an important tool in making a diagnosis, assessing symptoms, and monitoring progress. General observation of posture and movement is best augmented by specific focal observations that target examination abnormalities. Observation of the patient and their environment yields a wealth of diagnostic examination detail. Speech, gestures, transitional movements, gait, and manipulation of objects reflect the status of the neurologic and musculoskeletal systems. Other more constitutional findings, such as cyanosis, jaundice, pallor, diaphoresis, blanching, or flushing can 
Table 4 con't. Guide to the modified lumbar spine examination through telemedicine guide.

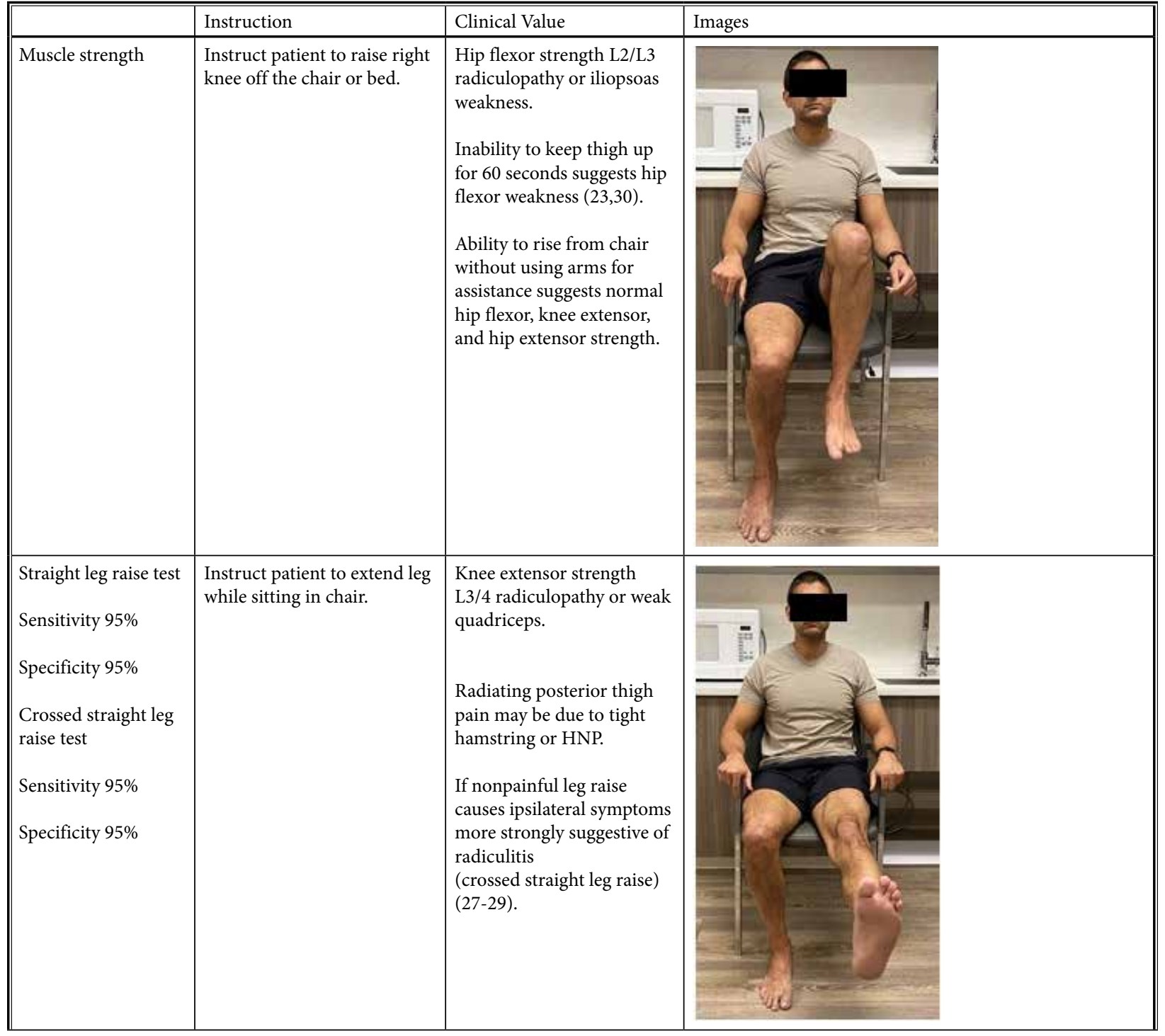

be evidence of disease in other systems. Visible personal objects and condition of their surroundings might provide insight into a patient's personality.

Symptom evaluation is typically a function of the history, but symptoms can also be assessed observationally in a standardized, validated format. One example of this is the BOS-3 (Behavioral Observation Scale 3) to assess pain. It grades verbal or nonverbal patients for specific facies, antalgic or analgesic postures and movements, and other observed pain behaviors.

A competent observer needs to recognize both the technical and personal limitations of the observed telemedicine examination. Many physical findings have a high degree of interobserver variability and should be deemphasized in favor of those with better repro- ducibility. Asymmetry remains an invaluable clue in the video examination (46). Patients should be observed while sitting, standing, transitioning, and walking. Scan the patient in an organized manner. Atrophy/ contour, posture/movement, and symmetry of the neck, trunk, pelvis, and extremities informs the subsequent examination.

In quiet stance, a patient should display no visible postural sway. The line of gravity should be anterior to the hips, behind the knees, and just in front of the ankle. There are multiple causes of visible postural sway but alteration in the line of gravity typically reflects a musculoskeletal derangement-either of skeletal misalignment or muscle/tendon tightness or contracture. Lumbar, thoracic, and cervical curves can be grossly 
Telemedicine During COVID-19 and Beyond

Table 4 con't. Guide to the modified lumbar spine examination through telemedicine guide.

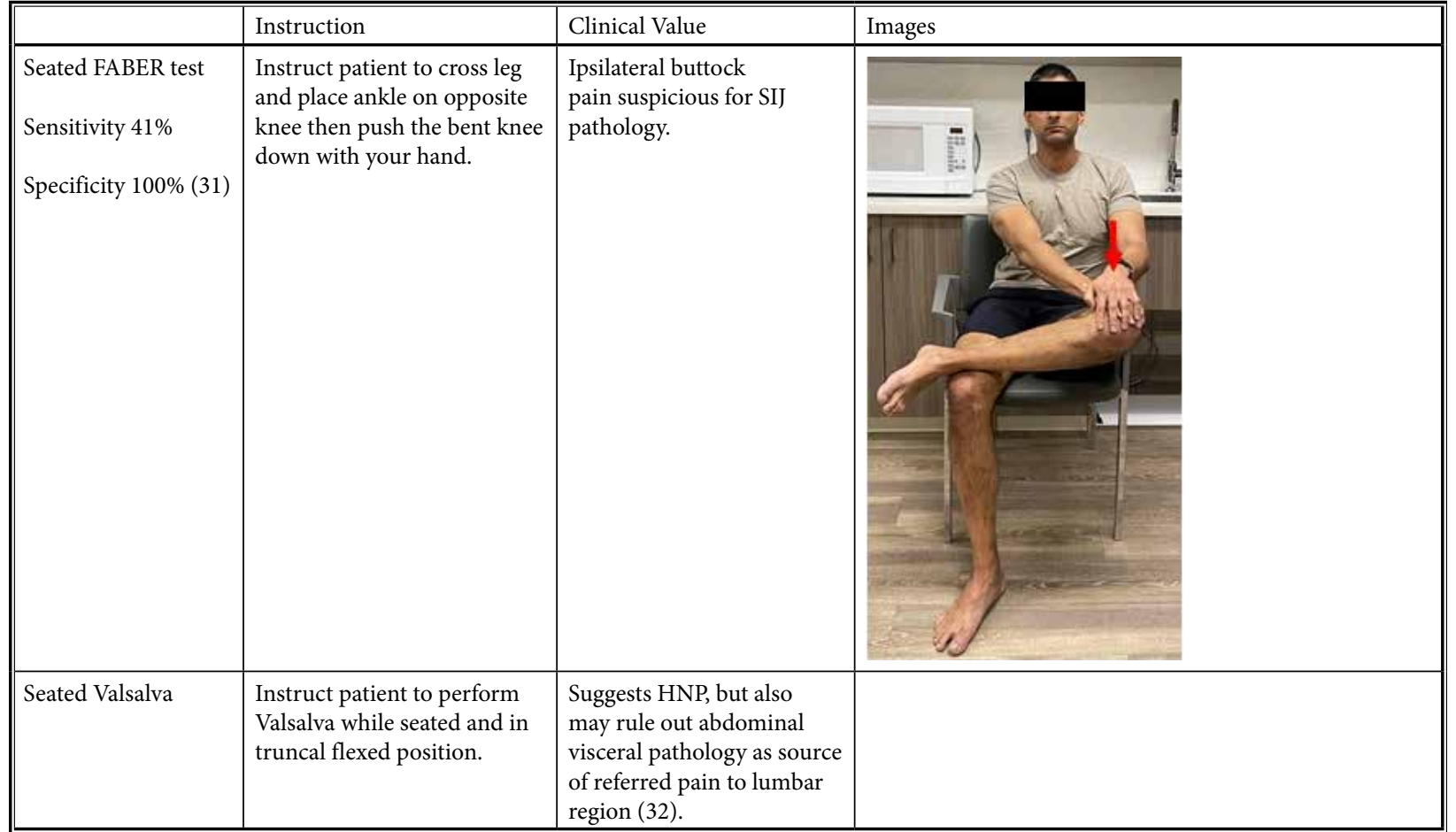

EDL, extensor digitorum longus; EHL, extensor hallucis longus; HNP, herniated nucleous pulposes; PSIS, posterior superior iliac spine; SIJ, sacroiliac joint; $\mathrm{TA}$, tibialis anterior.

Table 5. Guide to the modified hip examination through telemedicine guide.

\begin{tabular}{|c|c|c|c|}
\hline & Instruction & Clinical Value & Images \\
\hline Body Part & Hip Examination & & \\
\hline Physician props & Diagram of hip anatomy. & $\begin{array}{l}\text { Educate patient on hip } \\
\text { anatomy to describe } \\
\text { painful condition once } \\
\text { examination is complete. }\end{array}$ & \\
\hline Patient props & Chair and table. & $\begin{array}{l}\text { Chair will allow patient } \\
\text { to perform ROM and } \\
\text { provocative maneuvers. } \\
\text { Table for balance during } \\
\text { examination. }\end{array}$ & \\
\hline $\begin{array}{l}\text { Patient clothing and } \\
\text { prep }\end{array}$ & $\begin{array}{l}\text { Shorts allows visualization of } \\
\text { painful area. } \\
\text { Leggings/yoga pants, } \\
\text { nonrestrictive and allow ROM } \\
\text { assessment. } \\
\text { Ensure patient has } \\
\text { approximately } 6 \text { feet of space } \\
\text { in all directions and able } \\
\text { to position on the chair, and } \\
\text { away from the camera. }\end{array}$ & $\begin{array}{l}\text { Allow visualization of } \\
\text { examination of torso and } \\
\text { trunk. }\end{array}$ & \\
\hline
\end{tabular}


Table 5 con't. Guide to the modified hip examination through telemedicine guide.

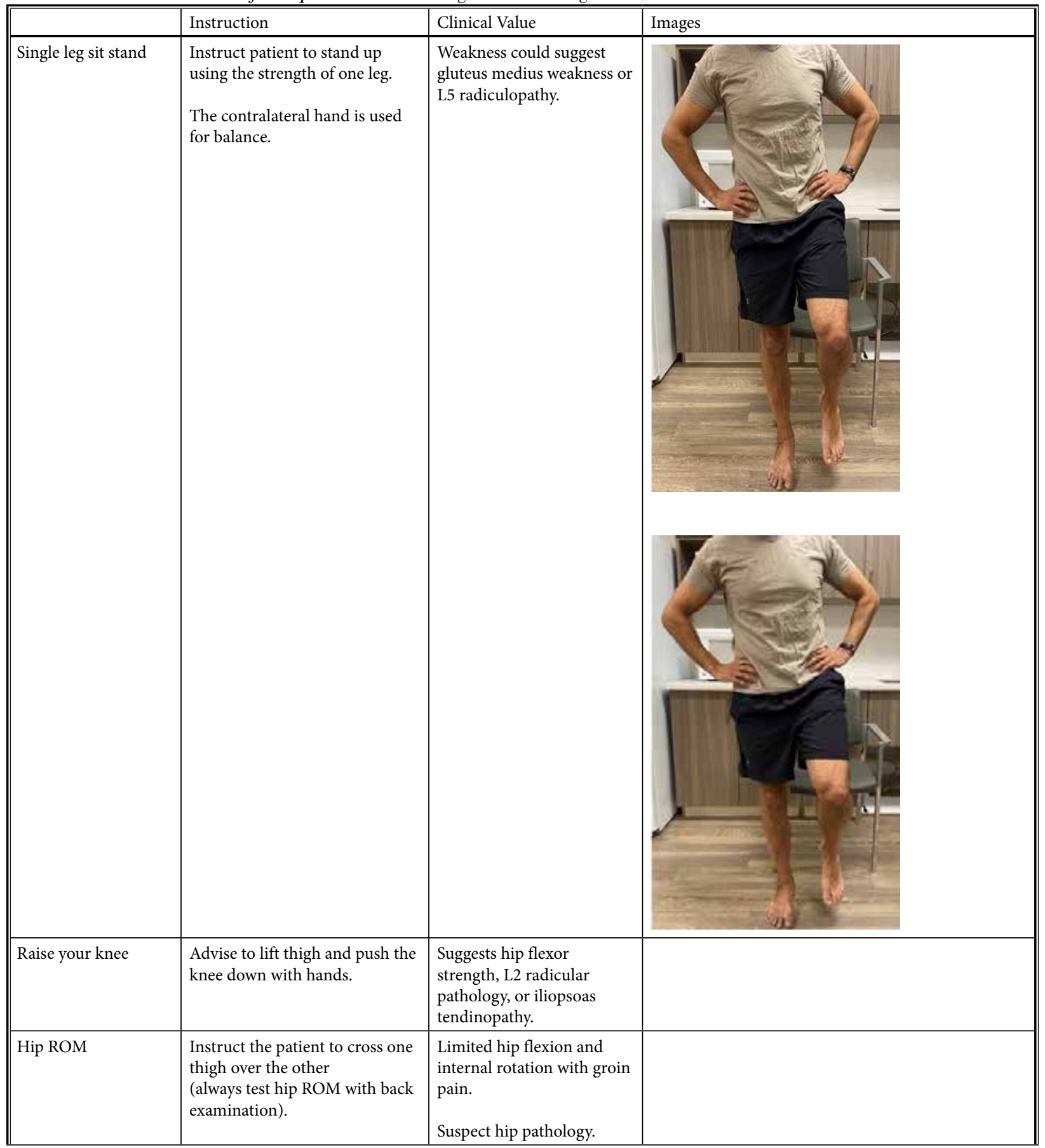

assessed by having the patient stand with their back against the wall, and any gapping between the occiput and wall or low back and wall noted. Bringing the shoulders to the wall gives a sense of shoulder protraction, whereas the gap between the wall and feet may suggest hamstring tightness. Looking at the patient from a lateral view will supplement information on spinal alignment and any restriction of muscles around the hips. Viewing the patient from behind might suggest a leg length discrepancy, as well as a scoliosis. Restricted 
Telemedicine During COVID-19 and Beyond

Table 5 con't. Guide to the modified hip examination through telemedicine guide.

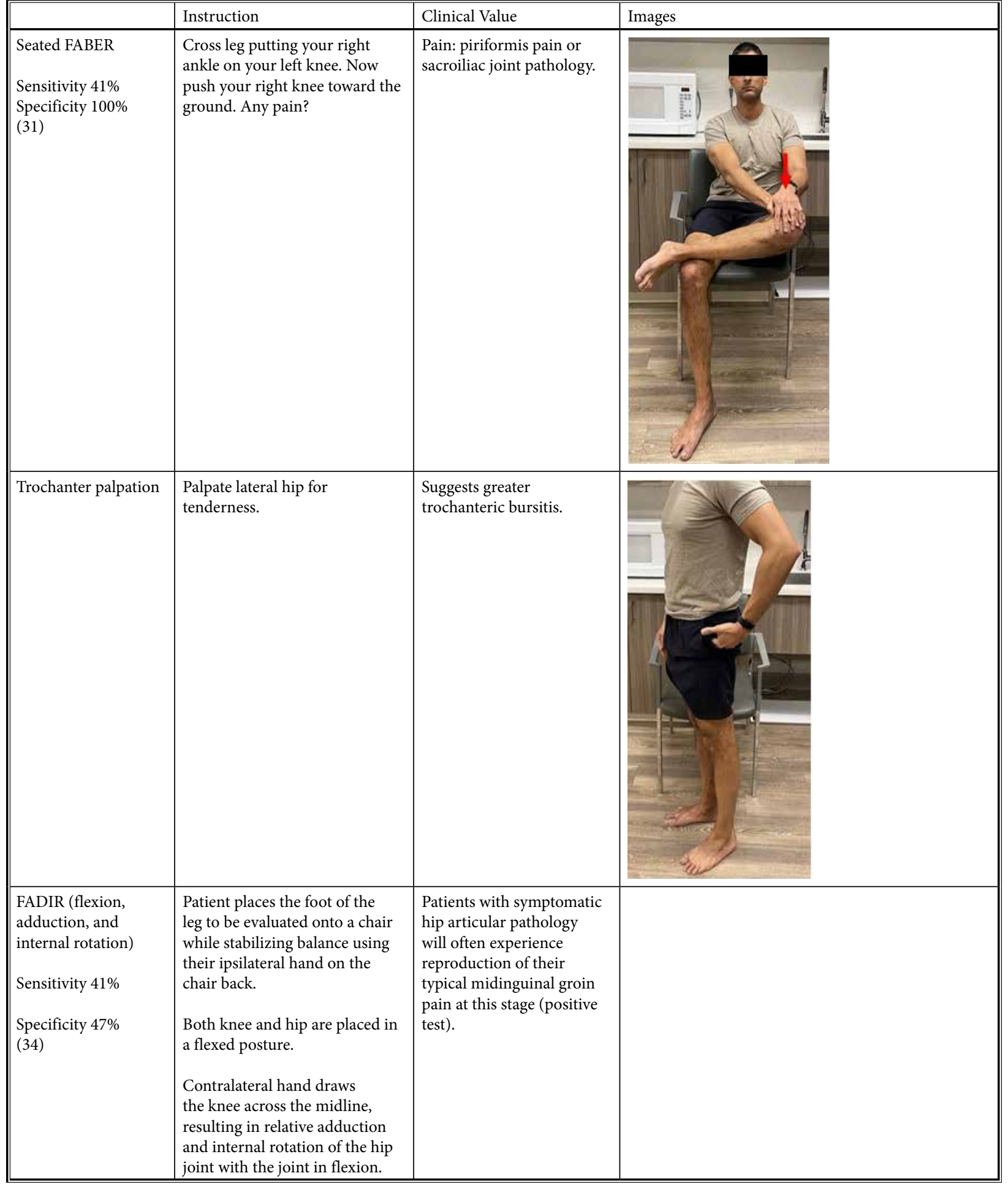


Table 6. Guide to the modified knee examination through telemedicine guide.

\begin{tabular}{|c|c|c|c|}
\hline Body Part & Knee Examination & Clinical Value & Images \\
\hline Previsit instructions & $\begin{array}{l}\text { Ensure patient has a } \\
\text { minimum of } 6 \text { feet of space } \\
\text { around them to position } \\
\text { yourself to stand and sit at a } \\
\text { chair, move from side to side } \\
\text { and forward and backward. } \\
\text { Position camera } 6 \text { feet away } \\
\text { so physician can see both } \\
\text { knees and thigh up to mid } \\
\text { orso. }\end{array}$ & $\begin{array}{l}\text { Mobility and position. } \\
\text { Patient may be asked to } \\
\text { sit and stand to observe } \\
\text { balance and sit-stand } \\
\text { position transition. }\end{array}$ & \\
\hline Physician props & Knee model or diagram. & $\begin{array}{l}\text { Educate patient on neck } \\
\text { anatomy to describe } \\
\text { painful condition once } \\
\text { examination is complete. }\end{array}$ & \\
\hline Patient props & $\begin{array}{l}2 \text { chairs } \\
\text { for use with examination. }\end{array}$ & $\begin{array}{l}\text { Maneuverability } \\
\text { and balance during } \\
\text { examination. }\end{array}$ & \\
\hline Patient clothing & $\begin{array}{l}\text { Dressed in shorts that end } \\
\text { above the knee. May need to } \\
\text { be rolled up for visualization } \\
\text { of quadriceps muscle. }\end{array}$ & $\begin{array}{l}\text { Allow visualization of } \\
\text { examination areas. }\end{array}$ & \\
\hline Inspection & $\begin{array}{l}\text { Instruct patient to stand in } \\
\text { front of chair with legs close } \\
\text { together for comparison. }\end{array}$ & $\begin{array}{l}\text { Compare for effusion, } \\
\text { abrasions, bruising, } \\
\text { ecchymosis, muscle } \\
\text { atrophy, patella alta and } \\
\text { baja, patella subluxation/ } \\
\text { dislocation. Assess for } \\
\text { unilateral lower extremity } \\
\text { edema and erythema to } \\
\text { rule out potential deep } \\
\text { venous thrombosis. } \\
\text { COVID infection and/ } \\
\text { or lack of activity due } \\
\text { to pain may induce } \\
\text { coagulopathy (2). }\end{array}$ & \\
\hline Gait & $\begin{array}{l}\text { Have patient walk back and } \\
\text { forth in front of camera. }\end{array}$ & $\begin{array}{l}\text { Assess gait pattern: } \\
\text { antalgic, hip rise, stance } \\
\text { phase, heel rise, swing } \\
\text { phase, heel rise, and toe } \\
\text { touch. }\end{array}$ & \\
\hline Palpation & $\begin{array}{l}\text { Have patient point to area of } \\
\text { tenderness or maximal pain. }\end{array}$ & $\begin{array}{l}\text { Helps confirm patient's } \\
\text { description of pain area. }\end{array}$ & 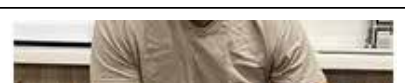 \\
\hline
\end{tabular}


Table 6 con't. Guide to the modified knee examination through telemedicine guide.

\begin{tabular}{|c|c|c|c|}
\hline Body Part & Knee Examination & Clinical Value & Images \\
\hline $\begin{array}{l}\text { Active straight leg } \\
\text { raise }\end{array}$ & $\begin{array}{l}\text { Instruct patient sit on one } \\
\text { chair with legs on another } \\
\text { chair close together. } \\
\text { Have patient do straight leg } \\
\text { raise. }\end{array}$ & $\begin{array}{l}\text { Checks for extensor } \\
\text { mechanism to evaluate } \\
\text { for quadriceps or patella } \\
\text { tendon rupture. }\end{array}$ & \\
\hline $\begin{array}{l}\text { Quadriceps } \\
\text { contraction }\end{array}$ & $\begin{array}{l}\text { Instruct patient sit on chair } \\
\text { and contract quadriceps. }\end{array}$ & $\begin{array}{l}\text { Checks for flexion } \\
\text { contracture/inability to } \\
\text { fully extend for possible } \\
\text { intraarticular pathology } \\
\text { (meniscus, osteochondral } \\
\text { defect, cruciate injury, } \\
\text { hamstring tightness). }\end{array}$ & \\
\hline ROM & $\begin{array}{l}\text { While still sitting with both } \\
\text { legs on other chair have } \\
\text { patient flex affected knee } \\
\text { then contralateral knee for } \\
\text { comparison. }\end{array}$ & $\begin{array}{l}\text { ROM with assessment } \\
\text { of pain. }\end{array}$ & \\
\hline
\end{tabular}

motion, atrophy or asymmetry of neck and shoulder posture, or reach when seated at rest can reflect muscle spasm or radiculopathy with related pain and should prompt more targeted observation for these diagnoses.

Does the patient need to supplement lower extremity strength or balance by use of their upper extremities when rising to stand? Is there an antalgic avoidance of heel strike as with advanced osteoarthritis? Does a foot slap indicate dorsiflexor weakness? A focused neuromusculoskeletal video examination should follow such findings. Expertly conducted, the clinical value of a video remote examination should have a value almost equivalent to that of an in-office assessment.

Academic pain centers (APCs), like most other medical practices, have been significantly affected by state and national orders to limit office visits and elective procedures. Many practices have truncated their services offered to telemedical visits and emergency visits only; some have completely closed. Although video encounters billing as E/M visits has helped maintain at least a portion of revenue and productivity, the pandemic has had devastating financial effects on many medical practices including APCs (48). Even now, as social distancing orders are starting to be lifted, it is unlikely that pain patients will be in a rush to return for both office visits and elective procedures until there is a reliable treatment or a vaccine for COVID-19. Two of the multiple reasons for this are that most pain patients are elderly and suffer from many comorbidities making them more susceptible, and there is some evidence that steroid injections are associated with increased viral pneumonia risk (49). Therefore telemedicine, and specifically video encounters, will remain our primary interaction with our patients into the foreseeable future.

In this unique and timely investigation, our group of experts has presented focused physical examination principles of the neck, shoulder, elbow/wrist/hand, back, hip, and knee that can be performed outside of the clinical setting and without physical clinician intervention. Our group has modified some examinations from their validated counterparts in order that they can be performed passively. Although our group does 
Table 6 con't. Guide to the modified knee examination through telemedicine guide.

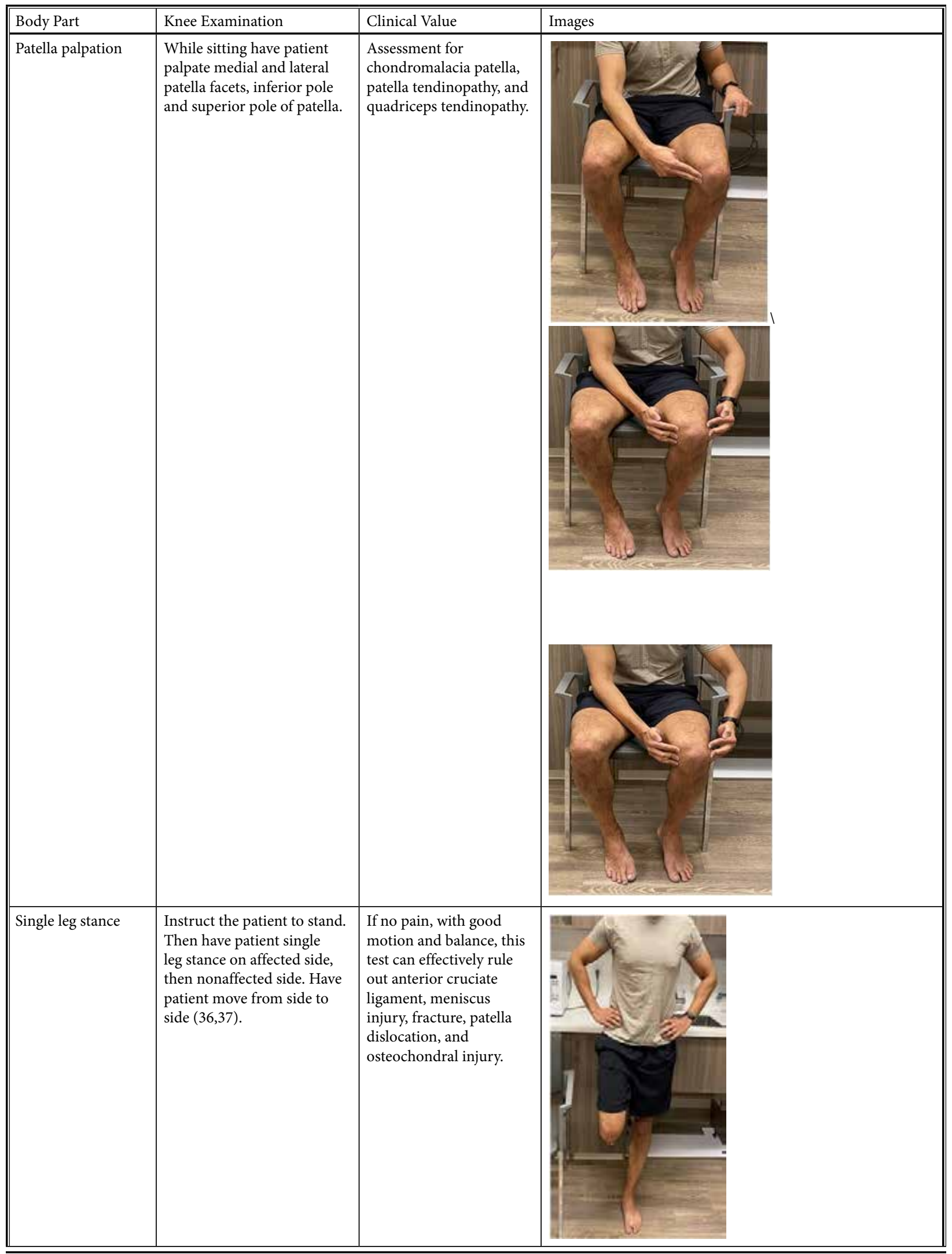


Telemedicine During COVID-19 and Beyond

Table 6 con't. Guide to the modified knee examination through telemedicine guide.

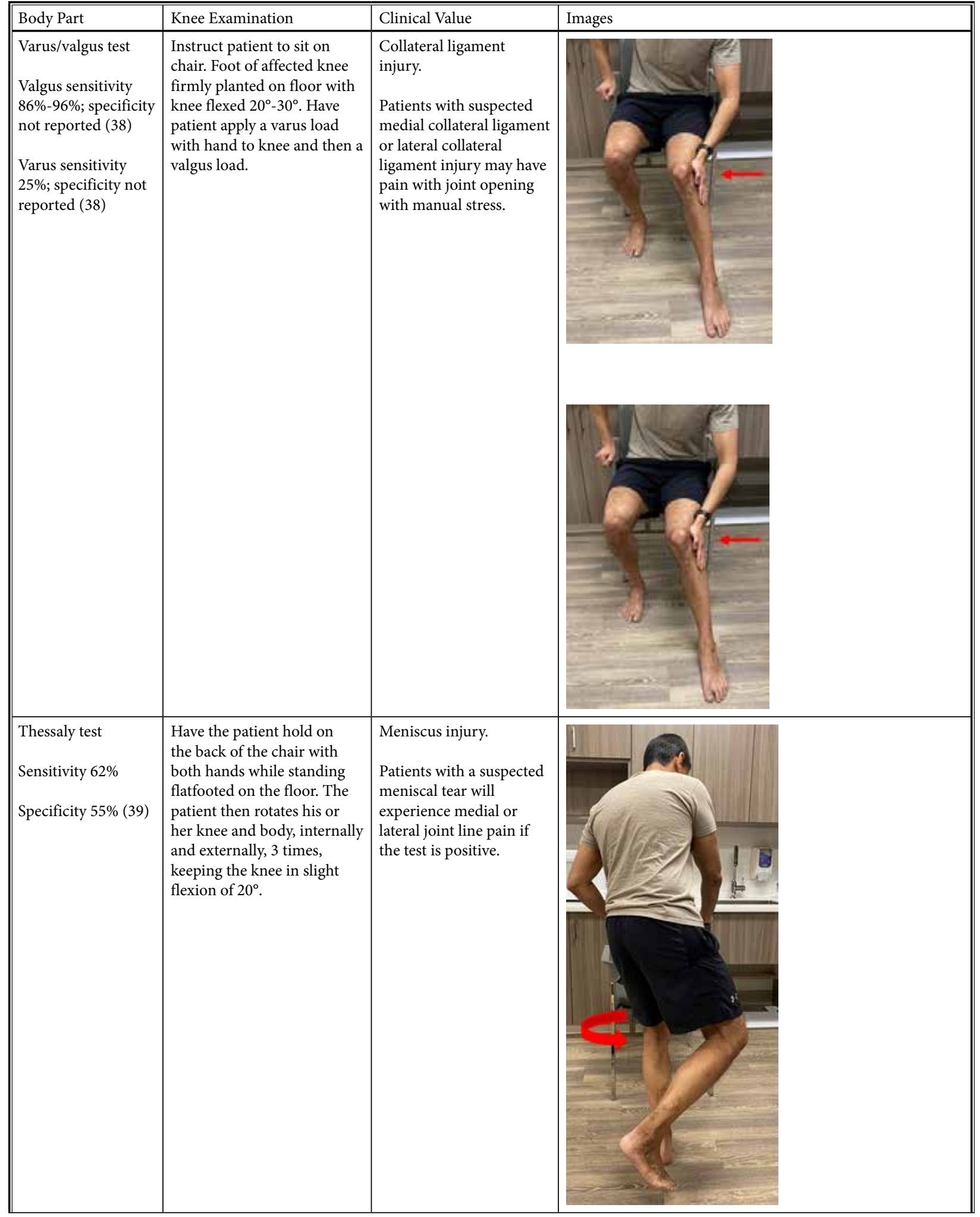


Table 6 con't. Guide to the modified knee examination through telemedicine guide.

\begin{tabular}{|c|c|c|c|}
\hline Body Part & Knee Examination & Clinical Value & Images \\
\hline $\begin{array}{l}\begin{array}{l}\text { Patella apprehension } \\
\text { test }\end{array} \\
\text { Sensitivity } 100 \% \\
\text { Specificity } 88 \%(40)\end{array}$ & $\begin{array}{l}\text { With patient sitting down } \\
\text { have patient put laterally } \\
\text { directed stress on patella } \\
\text { from medial side. }\end{array}$ & $\begin{array}{l}\text { Assessment for patella } \\
\text { instability. Test will show } \\
\text { apprehension and pain. }\end{array}$ & $y$ \\
\hline
\end{tabular}

not believe that our intervention devalues them, we do submit that further studies may be required to validate these recommendations for telemedicine use.

\section{Conclusions}

Pain is the most common complaint in the clinical setting, and, related to the current pandemic, dramatic changes in how health care is delivered is currently taking place. Telemedicine in pain management is now a necessity and requires methodical appreciation for the limits of this venue in assessment of pain states. In this regard, the physical examination is an essential component for sound clinical judgment and patient care planning. The physical examinations described in this investigation provide a comprehensive framework for the musculoskeletal and neurologic examination, which has been vetted by a committee of national experts for incorporation into the telemedicine evaluation.

\section{Author Contributions}

All the authors were involved in the conception, data collection, analysis, writing and revision of this article.

Dr. Wahezi is Associate Professor of Physical Medicine and Rehabilitation, Anesthesiology, and Orthopedic Surgery at Albert Einstein College of Medicine, Program Director of the Montefiore Multidisciplinary Pain Fellowship, Bronx, NY.

swahezi@montefiore.org

Dr. Duarte is Director of the Pain Center at North- well Health, Great Neck, NY; and Assistant Professor of Neurology at Hofstra North Shore-LIJ School of Medicine, Manhasset, NY.

RDuarte@northwell.edu

Dr. Yerra is Clinical Research Fellow at Physical Medicine and Rehabilitation at Montefiore Medical Center, Bronx, NY.

Drsandeepyerra@gmail.com

Dr. Thomas is Associate Professor of Physical Medicine and Rehabilitation at Albert Einstein College of Medicine, Bronx, NY; and Residency Training Program Director of Physical Medicine and Rehabilitation at Montefiore Medical Center, Bronx, NY.

mathomas@montefiore.org

Dr. Pujar is Clinical Research Coordinator at Montefiore Medical Center, Bronx, NY.

bpujar@montefiore.org

Dr. Sehgal is Chair Division of Rehabilitation Medicine, Vice Chair Department of Orthopedics \& Rehabilitation, University of Wisconsin School of Medicine \& Public Health, and Program Director, Pain Medicine (Multidisciplinary) Fellowship Program, University of Wisconsin, UW Health, Madison, WI.

Sehgal@rehab.wisc.edu

Dr. Gonzalez is Director of Orthopedic Sports Medicine at Montefiore Medical Center, Bronx, NY; and Assistant Professor of Orthopedic Surgery at Albert Einstein College of Medicine, Bronx, NY. dgonzale@montefiore.org Dr. Kim is Professor in Department of Physical Med- 
icine and Rehabilitation and Anesthesiology at Case Western Reserve University, Cleveland, OH; Program Director of the Pain Medicine Fellowship at Case Western Reserve University/MetroHealth, Cleveland, $\mathrm{OH}$; Director of the Musculoskeletal Rehabilitation Division in the Department of Physical Medicine and Rehabilitation at MetroHealth Medical Center, Cleveland, OH; Director of Pain and Healing Center at MetroHealth Medical Center, Cleveland, $\mathrm{OH}$; and Co-Director of the Spine Center at MetroHealth Medical Center, Cleveland, $\mathrm{OH}$. Ckim3@metrohealth.org

Dr. Ruchi Jain is Assistant Professor of Medicine, Rheumatology Division at Albert Einstein College of Medicine and Montefiore Medical Center, Bronx, NY. ruchjain@montefiore.org

Dr. Hossack is Director of Cartilage Restoration Surgery at Montefiore Medical Center, Professor of Orthopedic Surgery at Albert Einstein College of Medicine, Bronx, NY. mihossac@montefiore.org

Dr. Senthelal is a Fellow in the Multidisciplinary Pain Program Center at Montefiore Medical Center/ Albert Einstein College of Medicine, Bronx, NY. ssenthel@montefiore.org

Dr. Ankush Jain is a Fellow in the Multidisciplinary Pain Program Center at Montefiore Medical Center/ Albert Einstein College of Medicine, Bronx, NY. anjain@montefiore.org

Dr. Leo is a Fellow in the Multidisciplinary Pain Program Center at Montefiore Medical Center/Albert Einstein College of Medicine, Bronx, NY.

nleo@montefiore.org

Dr. Shaparin is Associate Professor in Department of Anesthesiology and Physical Medicine and Rehabilitation at Albert Einstein College of Medicine, Bronx, NY; Associate Professor of Family and Social Medicine at Albert Einstein College of Medicine, Bronx, NY; and Director of Pain Services at Montefiore Medical Center, Bronx, NY.

nshapari@montefiore.org

Dr. Argoff is Assistant Professor of Neurology at Albany Medical College, Albany, NY; and Director of the Comprehensive Pain Program at Albany Medical Center, Albany, NY. cargoff@nycap.rr.com

Dr. Daniel Wong is a Fellow in the Multidisciplinary
Pain Program Center at Montefiore Medical Center/ Albert Einstein College of Medicine, Bronx, NY. danwong@montefiore.org

Dr. Ashley Wong is a Fellow in the Multidisciplinary Pain Program Center at Montefiore Medical Center/ Albert Einstein College of Medicine, Bronx, NY. aswong@montefiore.org Dr. Nguyen is a Fellow in the Multidisciplinary Pain Program Center at Montefiore Medical Center/Albert Einstein College of Medicine, Bronx, NY. kinguyen@montefiore.org

Dr. Manchikanti is Co-Director, Pain Management Centers of America, Paducah, KY; Clinical Professor, Anesthesiology and Perioperative Medicine, University of Louisville, Louisville, KY; and Professor of Anesthesiology-Research, Department of Anesthesiology, School of Medicine, LSU Health Sciences Center, New Orleans, LA. drlm@thepainmd.com

Dr. Singh is Vice Chair and Associate Professor in the Department of Rehabilitation Medicine at Weil Cornell Medicine, New York, NY; and Adjunct Associate Professor of Rehabilitation and Regenerative Medicine at Columbia University College of Physicians and Surgeons, New York, NY.

jrs9012@med.cornell.edu

Dr. Grieco is Associate Professor of Neurology at North Shore-LIJ Medical Center, New Hyde Park, NY. ggrieco@northwell.edu

Dr. Patel is a Neurology Resident Physician at North Shore-LIJ Medical Center, New Hyde Park, NY. apatel40@northwell.edu

Dr. Merritt D. Kinon is Assistant Professor of Neurosurgery and Director of Spinal Surgery Education at Montefiore Medical Center/Albert Einstein College of Medicine, Bronx, NY. mkinon@montefiore.org Dr. Kaye is Vice-Chancellor of Academic Affairs, Chief Academic Officer, and Provost, Professor of Anesthesiology and Pharmacology, Toxicology, and Neurosciences, Louisiana State University Health Sciences Center, School of Medicine, Shreveport, LA; Professor of Anesthesiology and Pharmacology, LSU School of Medicine, New Orleans, LA; and Professor of Anesthesiology and Pharmacology, Tulane School of Medicine, New Orleans, LA.

akaye@Isuhsc.edu, alankaye44@hotmail.com 


\section{References}

1. COVID-19 dashboard by the Center for Systems Science and Engineering (CSSE) at Johns Hopkins University (JHU). ArcGIS. Available at: https:// gisanddata.maps.arcgis.com/ apps/opsdashboard/index.html\#/ bda7594740fd 40299423467b48egecf6. Accessed May 28, 2020.

2. Grimm CA. US Department of Health and Human Services. Office of Inspector General. Hospital experiences responding to the COVID-19 pandemic: Results of a National Pulse Survey March 23-27, 2020. April 2020, OEl-06-20-00300.

Available at: https://oig.hhs.gov/oei/ reports/oei-06-20-00300.asp. Accessed May 28, 2020.

3. Kohan L, Sobey C, Wahezi S, et al. Maintaining high quality multidisciplinary pain medicine fellowship programs: Part II: Innovations in clinical care workflow, clinical supervision, job satisfaction and postgraduation mentorship for pain fellows during the Covid-19 pandemic. Pain Med 2020 June 10. [Epub ahead of print].

4. Murray CJ, Atkinson C, Bhalla K, et al; U.S. Burden of Disease Collaborators. The state of US health, 1990-2010: Burden of diseases, injuries, and risk factors. JAMA 2013; 310:591-608.

5. Fejer R, Kyvik KO, Hartvigsen J. The prevalence of neck pain in the world population: A systematic critical review of the literature. Eur Spine J 2005; 15:834-848.

6. Hogg-Johnson $S$, van der Velde $G$, Carroll LJ, et al. The burden and determinants of neck pain in the general population. Spine (Phila Pa 1976) 2008; 33:S39-S51.

7. Binder Al. Neck pain. BMJ Clin Evid 2008; 2008:1103.

8. Fernández-De-Las-Peñas $\mathrm{C}$, HernándezBarrera V, Alonso-Blanco C, et al. Prevalence of neck and low back pain in community-dwelling adults in Spain: A population-based national study. Spine (Phila Pa 1976) 2011; 36:E213-E219.

9. Wainner RS, Fritz JM, Irrgang JJ, et al. Reliability and diagnostic accuracy of the clinical examination and patient self-report measures for cervical radiculopathy. Spine 2003; 28:52-62.

10. Cohen SP. Epidemiology, diagnosis, and treatment of neck pain. Mayo Clin Proc 2015; 90:284-299.

11. Khare S, Seth D. Lhermitte's sign: The current status. Ann Indian Acad Neurol 2015; 18:154-156.

12. Tong HC, Haig AJ, Yamakawa K. The Spurling test and cervical radiculopathy. Spine (Phila Pa 1976) 2002; 27:156-159.

13. Hippensteel KJ, Brophy R, Smith MV, Wright RW. Comprehensive review of provocative and instability physical examination tests of the shoulder. ] Am Acad Orthop Surg 2019; 27:395-404.

14. Cotter EJ, Hannon CP, Christian D, Frank RM, Bach Jr BR. Comprehensive examination of the athlete's shoulder. Sports Health 2018; 10:366-375.

15. Hegedus EJ, Goode AP, Cook CE, et al. Which physical examination tests provide clinicians with the most value when examining the shoulder? Update of a systematic review with meta-analysis of individual tests. Br J Sports Med 2012; 46:964-978.

16. Hegedus EJ, Goode A, Campbell S, et al. Physical examination tests of the shoulder: A systematic review with metaanalysis of individual tests. $\mathrm{Br} J \mathrm{~S}$ Med 2008; 42:80-92.

17. Goubau JF, Goubau L, Van Tongel A, Van Hoonacker P, Kerckhove D, Berghs B. The wrist hyperflexion and abduction of the thumb (WHAT) test: A more specific and sensitive test to diagnose de Quervain tenosynovitis than the Eichhoff's Test. J Hand Surg Eur Vol 2014; 39:286-292.

18. Saroja G, Aseer AL, Sai V. Diagnostic accuracy of provocative tests in lateral epicondylitis. Int J Physio Res 2014; 2:815-823.

19. Geraci Jr MC, Alleva JT. The physical examination of the spine and its functional kinetic chain. In: Cole AJ, Herring SA (eds). The Low Back Pain Handbook: A Practical Guide for the Primary Care Clinician. Philadelphia, Hanley \& Belfus, 1997: pp. 69-93.

20. Chronopoulos E, Kim TK, Park HB, Ashenbrenner D, McFarland EG. Diagnostic value of physical tests for isolated chronic acromioclavicular lesions. Am J Sports Med 2004; 32:655-661.

21. Bogduk N. Clinical Anatomy of the Lumbar Spine and Sacrum, 4th ed. London, Churchill Livingstone, 2005.

22. Frontera WR, DeLisa JA, Gans BM, Robinson LR, Bockenek W, Chae
J. DeLisa's Physical Medicine and Rehabilitation: Principles and Practice, 6th ed. Philadelphia, Wolters Kluwer, 2019.

23. Scholten P, Chekka K, Benzon HT. Physical examination of the patient with pain. In: Benzon HT, Raja SN, Fishman SM, Liu SS, Cohen SP (eds). Essentials of Pain Medicine, 4th ed. New York, Elsevier, 2018: pp. 27-38.

24. Cuccurullo S. Physical Medicine and Rehabilitation Board Review, 4th ed. New York, Demos Medical, 2019.

25. Reeves AG, Swenson RS. Disorders of the Nervous System. Evaluation of the patient with "numbness." Dartmouth Medical School. Available at: www.dartmouth.edu/ dons/part_2/ chapter_13.html. Accessed July 23, 2020.

26. Majlesi J, Togay $\mathrm{H}$, Unalan $\mathrm{H}$, Toprak $\mathrm{S}$. The sensitivity and specificity of the slump and the straight leg raising tests in patients with lumbar disc herniation.J Clin Rheumatol 2008; 14:87-91.

27. Tawa N, Rhoda A, Diener I. Accuracy of clinical neurological examination in diagnosing lumbo-sacral radiculopathy: A systematic literature review. BMC Musculoskelet Disord 2017; 18:93.

28. Van der Windt DA, Simons E, Riphagen II, et al. Physical examination for lumbar radiculopathy due to disc herniation in patients with low-back pain. Cochrane Database Syst Rev 2010; 2:CDoo7431.

29. Telli H, Telli S, Topal M. The validity and reliability of provocation tests in the diagnosis of sacroiliac joint dysfunction. Pain Physician 2018; 21:E367-E376.

30. Huber AM, Feldman BM, Rennebohm RM, et al. Validation and clinical significance of the Childhood Myositis Assessment Scale for assessment of muscle function in the juvenile idiopathic inflammatory myopathies. Arthritis Rheum 2004; 50:1595-1603.

31. Troelsen A, Mechlenburg I, Gelineck J, Bolvig L, Jacobsen S, Søballe K. What is the role of clinical tests and ultrasound in acetabular labral tear diagnostics? Acta Orthop 2009; 80:314-318.

32. Goldish GD, Quast JE, Blow JJ, Kuskowski MA. Postural effects on intraabdominal pressure during Valsalva maneuver. Arch Phys Med Rehabil 1994; 75:324-327.

33. Christmas C, Crespo CJ, Franckowiak SC, Bathon JM, Bartlett SJ, Andersen RE. 
How common is hip pain among older adults? Results from the Third National Health and Nutrition Examination Survey. J Fam Pract 2002; 51:345-348.

34. Casartelli NC, Brunner R, Maffiuletti $N A$, et al. The FADIR test accuracy for screening cam and pincer morphology in youth ice hockey players. J Sci Med Sport 2018; 21:134-138.

35. Nguyen US, ZhangY, ZhuY, Niu J, Zhang $B$, Felson DT. Increasing prevalence of knee pain and symptomatic knee osteoarthritis: Survey and cohort data. Ann Intern Med 2011; 155:725-732.

36. Lehmann T, Paschen L, Baumeister J. Single-leg assessment of postural stability after anterior cruciate ligament injury: A systematic review and metaanalysis. Sports Med Open 2017; 3:32.

37. Negahban $H$, Mazaheri $M$, Kingma I, van Dieën JH. A systematic review of postural control during singleleg stance in patients with untreated anterior cruciate ligament injury. Knee Surg Sports Traumatol Arthrosc 2014; 22:1491-1504.
38. Malanga GA, Andrus S, Nadler SF, McLean J. Physical examination of the knee: A review of the original test description and scientific validity of common orthopedic tests. Arch Phys Med Rehabil 2003; 84:592-603.

39. Konan S, Rayan F, Haddad FS. Do physical diagnostic tests accurately detect meniscal tears? Knee Surg Sports Traumatol Arthrosc 2009; 17:806-811.

40. Ahmad CS, McCarthy M, Gomez JA. Shubin Stein BE. The moving patellar apprehension test for lateral patellar instability. Am J Sports Med 2009; 37:791-796.

41. AAN Publications. NeuroBytes: The neurologic exam via telemedicine. Available at: https://learning.aan. com/diweb/catalog/item/id/5033281. Accessed May 28, 2020.

42. Lyden P. Using the National Institutes of Health Stroke Scale: A cautionary tale. Stroke 2017; 48:513-519.

43. Kumar SP, Ramasubramanian D. The Babinski sign--A reappraisal. Neurol India 2000; 48:314-318.
44. Haddox, JD. Pain-focused mental status examination. Curr Rev Pain 1999; 3:42-47.

45. Saleem SM, Pasquale LR, Sidoti PA, Tsai JC. Virtual ophthalmology: Telemedicine in a Covid-19 era. Am J Ophthalmol 2020 Apr 30. [Epub ahead of print].

46. Mills S, Nicolson KP, Smith BH. Chronic pain: A review of its epidemiology and associated factors in population-based studies. Br J Anaesth 2019; 123:e273-e283.

47. Yengo-Kahn AM, Hale AT, Zalneraitis $\mathrm{BH}$, Zuckerman SL, Sills AK, Solomon GS. The Sport Concussion Assessment Tool: A systematic review. Neurosurg Focus 2016; 40:E6.

48. Ferneini EM. The financial impact of COVID-19 on our practice. J Oral Maxillofac Surg 2020; 78:1047-1048.

49. Sytsma TT, Greenlund LK, Greenlund LS. Joint corticosteroid injection associated with increased influenza risk. Mayo Clin Proc Innov Qual Outcomes 2018; 2:194-198. 

Appendix 1. The modified neurologic examination through telemedicine guide.

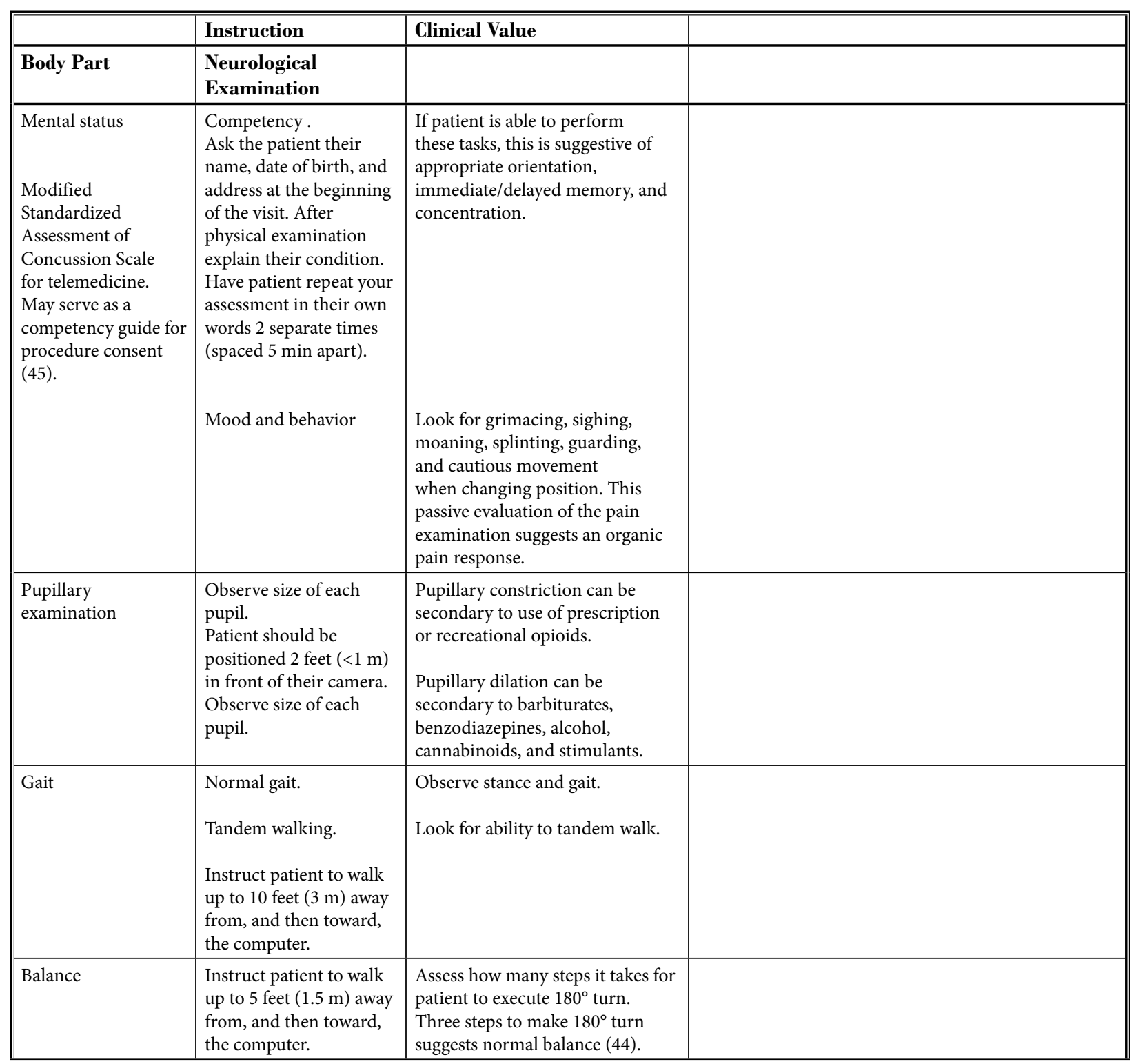


Appendix 1 (con't). The modified neurologic examination through telemedicine guide.

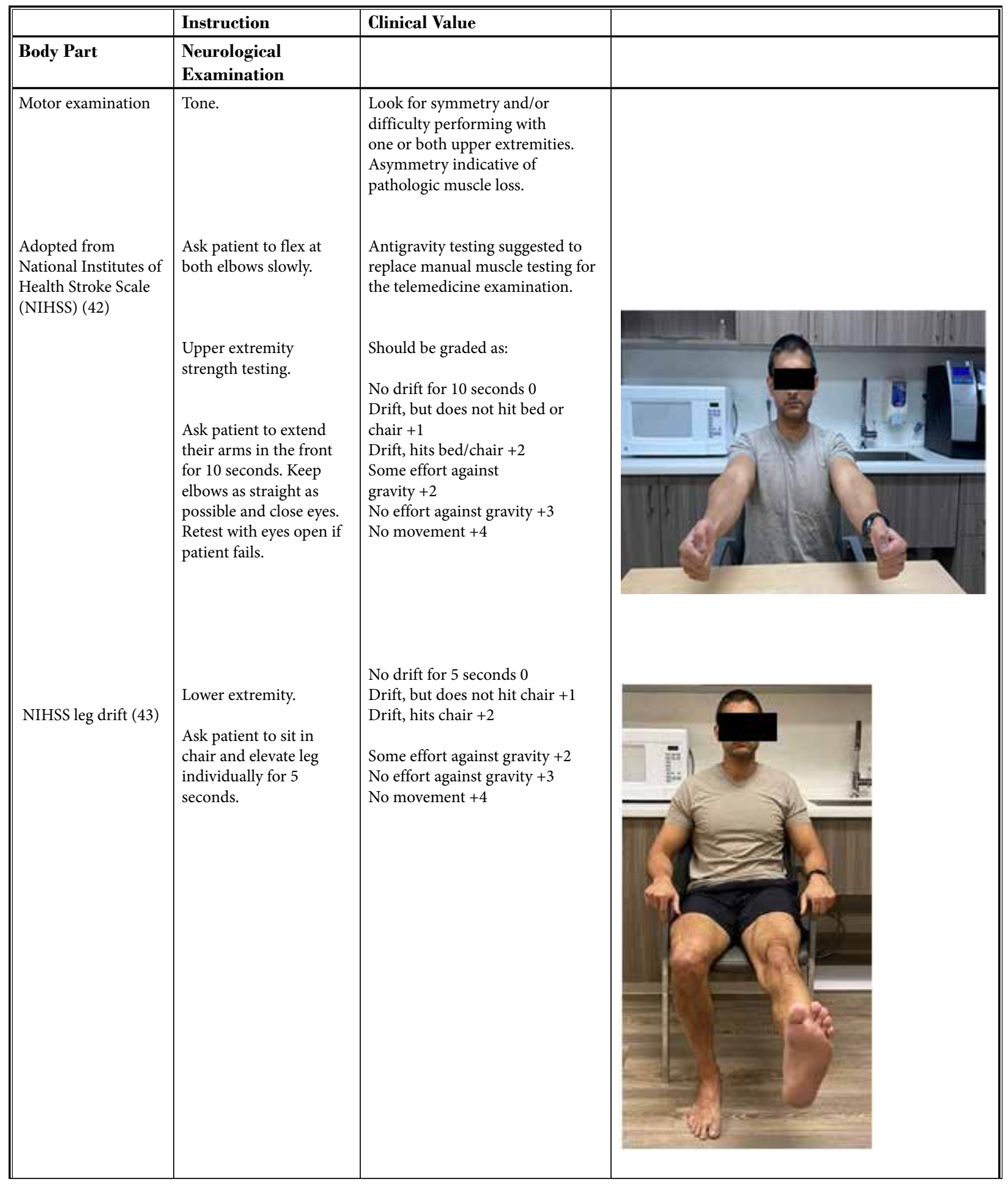


Appendix 1 (con't). The modified neurologic examination through telemedicine guide.

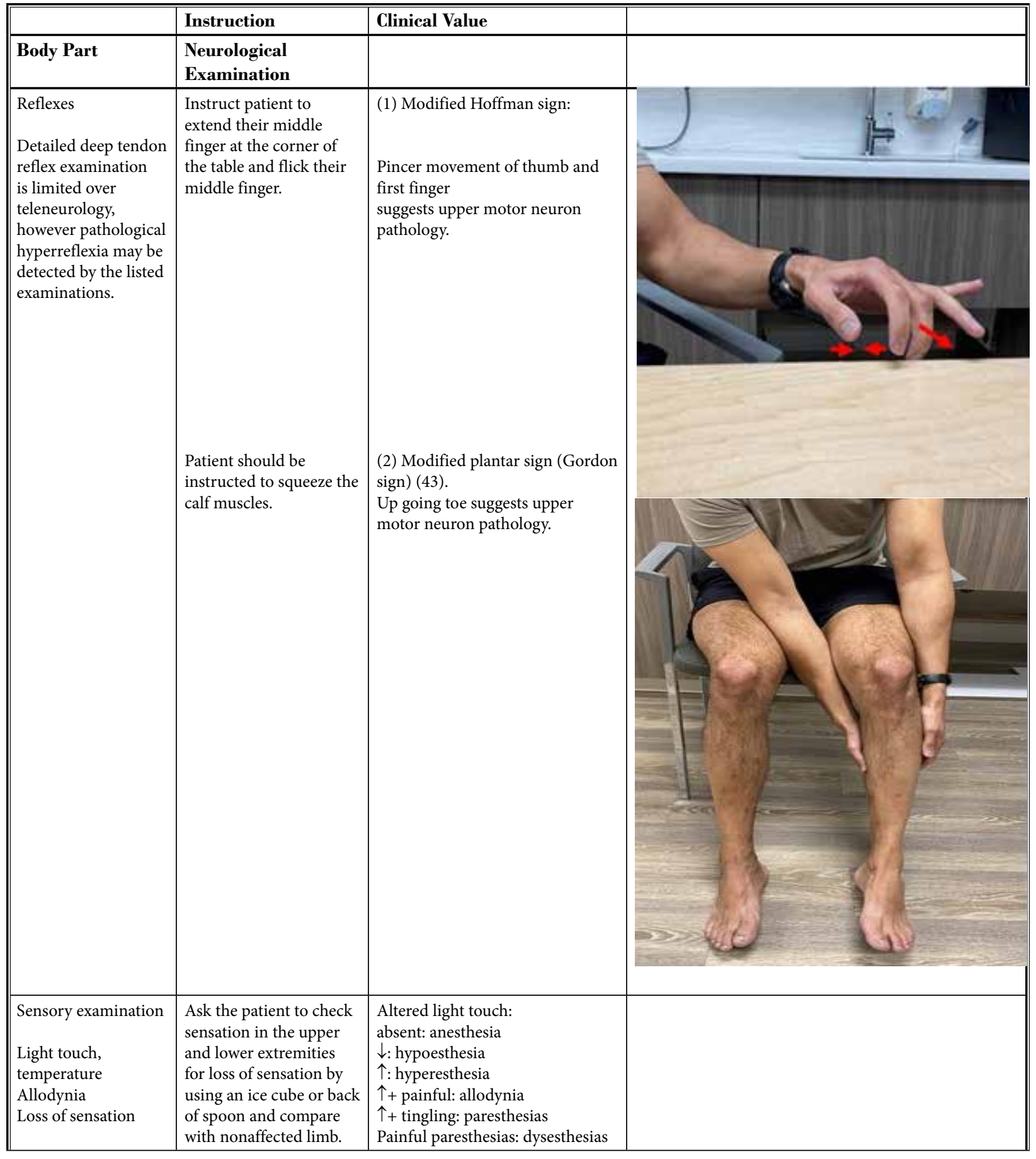


Appendix 1 (con't). The modified neurologic examination through telemedicine guide.

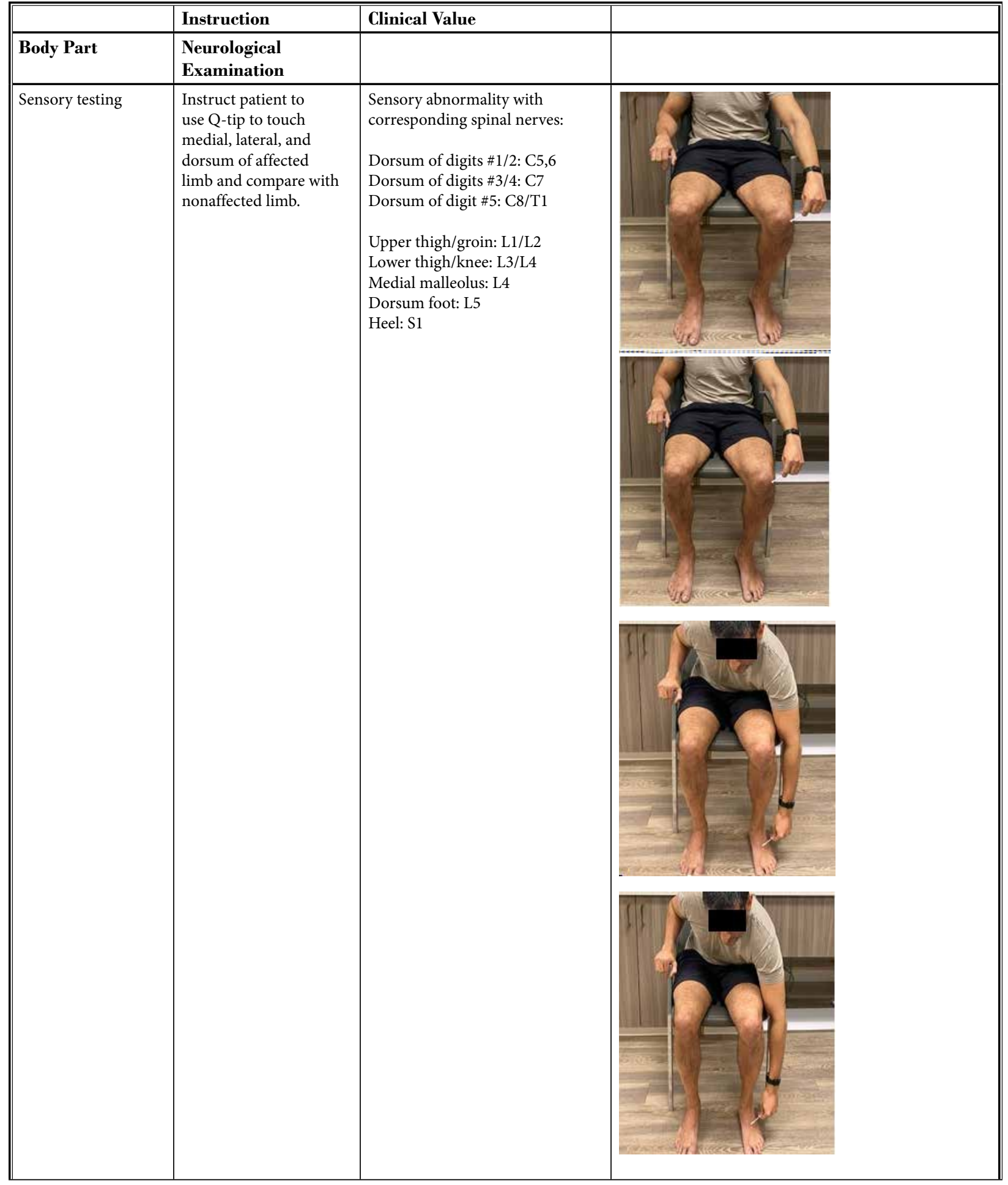


Appendix 1 (con't). The modified neurologic examination through telemedicine guide.

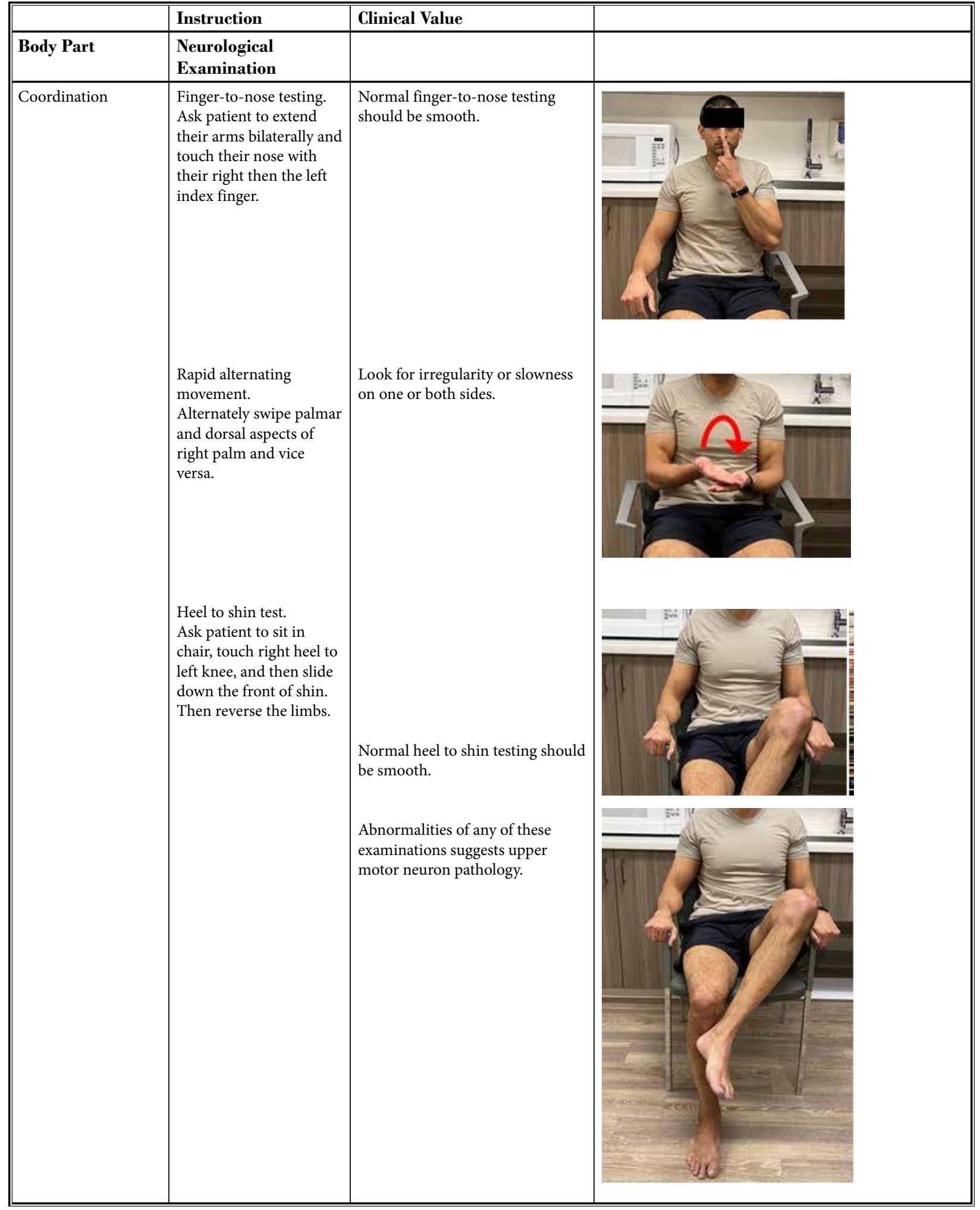

